\title{
The role of infections and coinfections with newly identified and emerging respiratory viruses in children
}

\author{
Maurizia Debiaggi ${ }^{1 \dagger}$, Filippo Canducci ${ }^{2^{*}}$, Elisa Rita Ceresola ${ }^{2}$ and Massimo Clementi ${ }^{2}$
}

\begin{abstract}
Acute respiratory infections are a major cause of morbidity in children both in developed and developing countries. A wide range of respiratory viruses, including respiratory syncytial virus (RSV), influenza A and B viruses, parainfluenza viruses (PIVS), adenovirus, rhinovirus (HRV), have repeatedly been detected in acute lower respiratory tract infections (LRTI) in children in the past decades. However, in the last ten years thanks to progress in molecular technologies, newly discovered viruses have been identified including human Metapneumovirus (hMPV), coronaviruses NL63 (HcoV-NL63) and HKU1 (HcoV-HKU1), human Bocavirus (HBoV), new enterovirus (HEV), parechovirus (HpeV) and rhinovirus (HRV) strains, polyomaviruses WU (WUPyV) and KI (KIPyV) and the pandemic H1N1v influenza A virus. These discoveries have heavily modified previous knowledge on respiratory infections mainly highlighting that pediatric population is exposed to a variety of viruses with similar seasonal patterns. In this context establishing a causal link between a newly identified virus and the disease as well as an association between mixed infections and an increase in disease severity can be challenging. This review will present an overview of newly recognized as well as the main emerging respiratory viruses and seek to focus on the their contribution to infection and co-infection in LRTIs in childhood.
\end{abstract}

\section{Introduction}

In the last decade thanks to progress in molecular technologies, newly discovered viruses have been identified. In 2001 human Metapneumovirus (hMPV) was identified, followed by discoveries or emergence of other respiratory viruses or virus strains: coronaviruses NL63 (HcoV-NL63) and HKU1 (HcoV-HKU1), human Bocavirus (HBoV), new enterovirus (HEV), parechovirus (HpeV) and rhinovirus (HRV) strains, polyomaviruses WU (WUPyV) and KI (KIPyV) and the pandemic H1N1v influenza A virus [1-8].

These discoveries have heavily modified previous knowledge on respiratory infections and have now highlighted that although until recently most viral lower respiratory infections in infants and young children were attributed to respiratory syncytial virus (RSV), PIVs, adenovirus, HRV and influenza viruses, pediatric

\footnotetext{
* Correspondence: canducci.filippo@hsr.it

${ }^{\dagger}$ Equal contributors

'Laboratorio di Virologia e Microbiologia, Università degli studi dell'Insubria' San Raffaele, Istituto Scientifico San Raffaele, Via Olgettina 58, 20132, Milan, Italy Full list of author information is available at the end of the article
}

population is indeed exposed to a variety of other viruses with a similar seasonal pattern [9-11]. In this context, establishing a causal link between a newly identified virus and the disease as well as an association between mixed infections and an increase in disease severity can be challenging. This review will present a brief overview of newly recognized as well as the main emerging respiratory viruses and seek to focus on the their contribution to infection and co-infection in LRTIs in childhood.

\section{Metapneumovirus}

Metapneumovirus was first recognized in 2001 in the Netherlands from nasopharyngeal aspirates collected during a 20-year period in 28 hospitalized children and infants with acute respiratory tract infection (RTI) having signs and symptoms similar to that of RSV infection [4]. The virus genomic sequence was identified by using a randomly primed PCR protocol and revealed to be closely related to the avian pneumovirus, a member of the Metapneumovirus genus, in the Paramixoviridae family, Initial studies following the first hMPV identification indicate that it causes

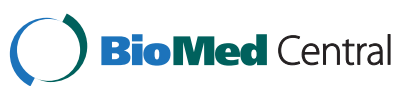


upper and lower RTIs in patients of all ages, but mostly in children aged below 5 years [12-17]. A large epidemiological retrospective study examined nasal washes collected over a 20-year period during acute respiratory illnesses in an outpatient cohort of children [18]. Over the entire study period, hMPV was detected in $1 \%-5 \%$ of pediatric upper RTIs (UTRIs), with variation from year to year. Several reports indicate that hMPV is a commonly identified cause of pediatric lower RTIs, and is second only to RSV as cause of bronchiolitis in early childhood [16,19-25]. While bronchiolitis, is the most common presentation of hMPV illness, other reported syndromes have included asthma exacerbation, otitis media, flulike illness, and communityacquired pneumonia [12,15,26-29]. Several studies have found hMPV $-\mathrm{RSV}$ co-infection rates of approximately 514\% [30-34]. Nevertheless, in a study conducted in the Netherlands in children admitted to hospital for lower RTIs (LRTIs), no virus co-infection between RSV and hMPV was detected [35]. Different controversial reports suggest an association between RSV-hMPV coinfection and an increase in the disease severity or the absence of an association between dual infection and disease severity. Greensill and colleagues [36] reported a 70\% rate of co-infection with hMPV in a cohort of infants with critical RSV bronchiolitis who required intensive care in the United Kingdom, suggesting that dual infection with RSV and hMPV may predispose for a more severe disease. In another study from the United Kingdom, hMPV and RSV co-infection was associated with increased disease severity and higher risk of admission to the pediatric intensive care unit [37]. Similar findings are supported by other studies suggesting that in young children, coinfections with RSV and hMPV are more severe than infections with either RSV or hMPV alone, requiring a longer hospitalization and supplemental oxygenation $[38,39]$. However, such synergistic association has not been found in other population-based and case-control studies of hospitalized children [16,33-35,40-42]. In particular, two studies evaluated the epidemiology of hMPV coinfection in children with LRTI caused by RSV and demonstrated no hMPV and RSV co-infection in mechanically ventilated children suggesting that co-infection with hMPV is not associated with a more severe course of RSV-LRTI $[35,42]$. In addition, in a prospective 2-year study in hospitalized infants with acute respiratory diseases, the role of RSV as a major respiratory pathogen was not influenced by the cocirculation of other emerging viral agents with similar seasonal distribution. In particular, RSV-hMPVs co-infections were significantly observed in less severe respiratory disease when compared to unique RSV infections [34]. The possible synergistic interaction between hMPV and the severe acute respiratory syndrome (SARS) coronavirus was also suggested during the 2003 SARS outbreak in Hong Kong and Canada [43,44]. In one case report, in an infant with SARS CoV infection, fatal encephalitis was correlated with
hMPV infection as hMPV RNA was detected postmortem in brain and lung tissue [26]. Nevertheless, in experimental studies performed in macaques, a synergy between hMPV and SARS was not confirmed [45]. In addition, infections of hMPV with respiratory viruses different from RSV, have also been occasionally reported but no sufficient data are available to discuss epidemiology or association with clinical disease presentation $[34,46,47]$ (Table 1$)$.

\section{Coronaviruses}

Following the discovery of SARS-CoV, other human coronaviruses, HCoV-NL63 and HCoV-HKU1, were identified and recognized to be common causes of communityacquired respiratory infections.

HCoV-NL63, a member of the group I coronaviruses, was first detected in 2004 in the Netherlands from a child with bronchiolitis by using a new method for virus discovery based on the cDNA-amplified restriction fragment-length polymorphism technique (cDNAAFLP) [3].

HCoV-HKU1, a group II coronavirus, was first detected in Hong Kong in 2005 from an adult patient with chronic pulmonary disease [1]. All attempts to grow a virus from his respiratory secretions failed until recently [48], but coronavirus RNA was initially detected by RT-PCR using pol gene consensus primers.

Like other coronaviruses, NL63 and HKU1 can also be detected in individuals of all ages, including elderly patients with fatal outcome [49] and those with underlying diseases of the respiratory tract [1]. However most frequently, the newly discovered coronaviruses are reported in 7 to 12-month old children with both upper and lower RTIs [34,49-53]. In studies conducted in children hospitalized with RTIs in China, from $2.6 \%$ to $3.8 \%$ of patients were positive for HCoV-NL63 and, in addition to causing upper respiratory disease, $\mathrm{HCoV}$ NL63 was found in croup, asthma exacerbation, febrile seizures, wheezing and high fever cases $[54,55]$. The occurrence of co-infection with NL63 and other respiratory viruses, including other human coronaviruses, RSV, PIV, influenza A and B viruses and hMPV has been reported [34,55-58]. In a large study from Germany evaluating children under 3 years of age with LRTIs, most co-infections were with RSV-A, probably because of the high percentage of RSV-A infections and an overlap in seasonality. In addition, double infection of NL63 with RSV-B, and with PIV3 occurred in a minority of cases. HCoV-NL63 co-infection with RSV-A occurred predominantly in the hospitalised patients in contrast to HCoV-NL63 co-infections with PIV3 that were exclusively present in the outpatient group [59].

Following the first identification, HKU1 was found in respiratory samples from elderly patients and children 
mainly with underlying diseases $[1,33,52,60]$. The most common symptoms are rhinorrhea, fever, and abdominal breath sounds [33], but pneumonia, bronchopneumonia, bronchiolitis, and acute asthma exacerbations were also described in children in China $[61,62]$.

In a study aimed to evaluate the overall prevalence of 10 respiratory viruses in children with acute LRTIs in China from 2006 to 2009, 73.47\% of the HCoV-HKU1 and HCoV-NL63-positive samples tested positive for at least one other virus, most commonly HRV and RSV [54]. Similar data describing a high rate of coinfection of coronaviruses with RSV has also been previously reported [63]. In a report from the UK both dual and single infections associated with respiratory outcomes were observed for HKU1 as well as for NL63 and OC43 coronaviruses [51]. In this study a high number of coinfections was observed for HKU1, NL63 as well as for OC43, mostly with RSV. Similar rates of lower and upper infections were observed in single HKU1 or OC43 infection compared with coinfection, whereas both URTI and LRTI were observed more frequently in single compared to mixed infection with NL63. No differences in clinical outcome were observed between single and dual infections with RSV and Coronaviruses NL63, HKU1 or OC43 indicating that RSV may presumably facilitate coronavirus infection without increasing disease severity. However, in the same study considering viral load data, a role of these coronaviruses in coinfections in respiratory disease was suggested. In fact no differences were observed when coronavirus load was evaluated in single infection and in RSV coinfection, indicating both that infection with another respiratory virus does not affect the ability of NL63, HKU1 or OC43 to establish infection and replicate, and that detection of coronaviruses in mixed infection should not be considered a secondary infection without contribution to disease pathogenesis [51]. This quantitative evaluation is in contrast with previous results obtained by van der Hoek and colleagues describing a significantly lower HCoV-NL63 viral load in patients coinfected with RSV or PIV3 than in patients infected with HCoV-NL63 alone [59]. However, the prolonged persistence of HCoV-NL63 at low levels, the different time of sampling relative to the time of disease onset, or the use of different diagnostic technologies could have affected these evaluations (Table 1).

\section{Bocavirus}

Human Bocavirus (HBoV) was discovered in 2005, in Sweden by Allander and colleagues by using a largescale molecular viral screening technique including DNase sequence-independent single-primer amplification [6]. Since initial observations, several studies have reported the prevalence of human Bocavirus infection all over the world ranging from 2 to $21.5 \%$, mainly in children younger than 3 years of age where it has been associated with upper and with lower RTIs [64-69]. In a study from Norway, $\mathrm{HBoV}$ was detected in $12 \%$ of children with RTI and it was the fourth most common virus after RSV, HRV and hMPV [70]. Recently, in children with radiographically confirmed community acquired pneumonia in which 17 respiratory viruses were tested during the acute phase of the disease, $\mathrm{HBoV}$ was the most frequently detected virus after RSV and HRV [71]. Since the discovery of the first $\mathrm{HBoV}$ (HBoV1), three other related bocaviruses (HBoV2, 3 and 4) have been identified in stool samples and associated with gastrointestinal diseases [72,73]. Serological studies on HBoV1 are in line with molecular data.

Serological studies have shown that the mere presence of $\mathrm{HBoV}$ DNA in the respiratory tract is not proof of an acute primary infection [65,74-76]. These data are also supported by studies on consecutive respiratory samples showing that HBoV DNA can persist for several months in the respiratory tract [77-79]. Prolonged viral shedding could explain both data reported in some papers in which HBoV DNA was found more often in asymptomatic than symptomatic cases $[79,80]$ and the high percentage of co-infections. In fact, $\mathrm{HBoV}$ infections tend to be associated with high rates of coinfections with other viral pathogens such as HRV, adenoviruses, RSV, as well as with bacteria such as Streptococcus spp and Mycoplasma pneumoniae [46,54,68-70,77,81-83]. Characteristics of persistence and high frequency of coinfections have led to a debate over its role as a true pathogen [84]. Our current knowledge of $\mathrm{HBoV}$ infection suggests that the virus is sometimes a passenger and sometimes a pathogen in acute respiratory tract disease and that diagnosis should not be solely based on qualitative PCR in respiratory samples. Indeed, in many studies a positive correlation was seen between respiratory illness and high copy numbers of HBoV1 DNA or the presence of HBoV1 monoinfection [68,75,85-87]. A study performed by Allander and colleagues suggests that acute $\mathrm{HBoV}$ infections are associated with the presence of viral DNA in the blood of patients. In fact, HBoV DNA was reported more frequently in patient blood during the acute symptoms than after recovery [68]. In addition, high load and viremic $\mathrm{HBoV}$ infection were associated with respiratory tract symptoms, while detection of a low viral load in the nasopharinx alone resulted to have no clinical relevance [68]. Other studies confirmed that $\mathrm{HBoV}$ is the most probable cause of respiratory tract disease if the patient has a single infection and high viral load in NPA and viremia [65,70]. However, despite these diagnostic challenges it is becoming increasingly evident that $\mathrm{HBoV} 1$ is an important respiratory pathogen [88]. Severe and life-threatening disease has been recently well documented in a 8-month-old 
Table 1 Recent epidemiological papers on respiratory infections and co-infections

VIRUSES ANALYSED (detection methods)

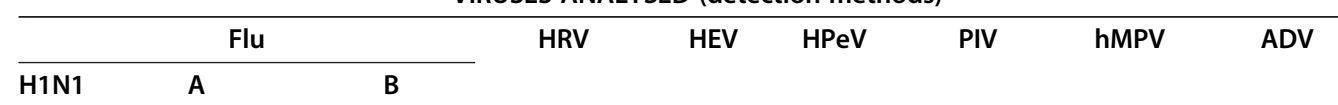

\begin{tabular}{|c|c|c|c|c|c|c|c|c|c|}
\hline Greensill, 2003 & & & & & & & & $X(a)$ & \\
\hline Viazov, 2003 & & & & & & & & $X(a)$ & \\
\hline Esper, 2004 & & & & & & & & $X(a)$ & \\
\hline Xepapadaki, 2004 & & $X(a)$ & $X(a)$ & $X(a)$ & & & $X(a)$ & $X(a)$ & $X(a)$ \\
\hline Konig, 2004 & & & & & & & & $X(a)$ & \\
\hline Semple, 2005 & & & & & & & & $X(a)$ & \\
\hline van Woensel, 2006 & & & & & & & & $X(b)$ & \\
\hline Foulongne, 2006 & & (d) & (d) & & & & (d) & $X(a)$ & (d) \\
\hline Lazar, 2004 & & & & & & & & $X(a)$ & \\
\hline Canducci, 2008 & & & & & & & & $X(a)$ & \\
\hline Chiu, 2005 & & (d) & (d) & & & & (d) & $X(a)$ & (d) \\
\hline van der Hoek,2006 & & $X(a)$ & $X(a)$ & & & & $X(a)$ & & \\
\hline \multicolumn{10}{|l|}{ Dare, 2007} \\
\hline Kuypers, 2007 & & $X(a)$ & & & & & $X(a)$ & $X(a)$ & $X(a)$ \\
\hline Minosse, 2008 & & & & $X(a)$ & & & & & $X(a)$ \\
\hline Wu, 2008 & & & & & & & & $x$ & $x$ \\
\hline Gaunt, 2010 & & $x(b)$ & $x(b)$ & & & & $X(b)$ & & $X(b)$ \\
\hline Choi, 2006 & & $X(a)$ and $(d)$ & $X(a)$ and $(d)$ & $X(a)$ & & & $X(a)$ and $(d)$ & $X(a)$ & $X(a)$ and $(d)$ \\
\hline Allander, 2007 & & $X(b),(c),(d),(e)$ & $X(b),(c),(d),(e)$ & $(c),(e), X(a)$ & (c), (e), X(a) & & $X(b),(c),(d),(e)$ & (c), X(a) & $X(b),(d),(e)$ \\
\hline Christensen, 2008 & & $x(b)$ & $x(b)$ & $X(b)$ & $X(b)$ & & $X(b)$ & $x(b)$ & $X(b)$ \\
\hline Dina, 2009 & & $X(a)$ & $X(a)$ & $X(a)$ & & & $X(a)$ & $X(a)$ & $(d),(c), X(b), x(a)$ \\
\hline Wang, 2010 & & $X(a)$ & $X(a)$ & $X(a)$ & & & $X(a)$ & $X(a)$ & $X(a)$ \\
\hline Don, 2010 & & (e) & (e) & & & & (e) & (e) & (e) \\
\hline Soderlund-Venermo, 2009 & & $X(a)$ & $X(a)$ & $X(a)$ & $X(a)$ & & $X(a)$ & $X(a)$ & $X(a)$ \\
\hline Martin, 2010 & & $X(a)$ & $X(a)$ & $X(a)$ & & & $X(a)$ & $X(a)$ & $X(a)$ \\
\hline Jin, 2012 & & $X(a)$ & $X(a)$ & $X(a)$ & & & $X(a)$ & $X(a)$ & $X(a)$ \\
\hline Esposito, 2012 & & $X(a)$ & $X(a)$ & $X(b)$ & $X(b)$ & & $X(a)$ & $X(a)$ & $X(a)$ \\
\hline Le, 2007 & & $X(a)$ & $X(a)$ & $X(a)$ & & & $X(a)$ & $X(a)$ & $X(a)$ \\
\hline Han, 2007 & & $X(a)$ & $X(a)$ & $X(a)$ & & & $X(a)$ & $X(a)$ & $X(a)$ \\
\hline Bialasiewicz, 2008 & & $X(a)$ & $X(a)$ & $X(a)$ & & & $X(a)$ & $X(a)$ & $X(a)$ \\
\hline Neske, 2008 & & (d) & (d) & & & & (d) & & (d) \\
\hline \multicolumn{10}{|l|}{ Babakir-Mina, 2010} \\
\hline Debiaggi, 2010 & & $X(a)$ & $X(a)$ & $X(a)$ & & & $X(a)$ & $X(a)$ & $X(a)$ \\
\hline Zhuang, 2011 & & $x(b)$ & $\mathrm{X}(\mathrm{b})$ & $x(b)$ & & & $X(b)$ & $x(b)$ & $x(b)$ \\
\hline Rao, 2011 & & $X(a)$ & $X(a)$ & $X(a)$ & & & $X(a)$ & $X(a)$ & $X(a)$ \\
\hline Lau, 2007 & & (d) & (d) & $X(a)$ & & & (d) & $X(a)$ & (d) \\
\hline Harvala, 2008 & & $X(a)$ & $X(a)$ & & & $X(a)$ & $X(a)$ & $X(a)$ & $X(a)$ \\
\hline Jin, 2009 & & $X(a)$ & $X(a)$ & $X(a)$ & & & $X(a)$ & $X(a)$ & $X(a)$ \\
\hline Miller, 2009 & & & & $X(a)$ & & & & & \\
\hline Yozwiak, 2010 & & & & & $X(a)$ & & & & \\
\hline Debiaggi, 2012 & & $X(a)$ & $X(a)$ & $X(a)$ & $X(a)$ & & $X(a)$ & $X(a)$ & $X(a)$ \\
\hline Piralla, 2012 & & $X(a)$ & $X(a)$ & $X(a)$ & $X(a)$ & $\mathrm{X}(\mathrm{b})$ & $X(a)$ & $X(a)$ & $X(a)$ \\
\hline Renois, 2010 & $X(a)$ & $X(a)$ and $X(b)$ & $X(a)$ & $X(a)$ & $X(a)$ & & $X(a)$ & $X(a)$ & $X(a)$ \\
\hline Casalegno, 2010 & $X(\mathbf{b})$ & & & $X(b)$ & & & & & \\
\hline
\end{tabular}


Table 1 Recent epidemiological papers on respiratory infections and co-infections (Continued)

\begin{tabular}{|c|c|c|c|c|c|c|}
\hline Schnepf, 2011 & & $X(b$ & & $X(a)$ & $X(a)$ & $X(a)$ \\
\hline \multicolumn{7}{|c|}{ VIRUSES ANALYSED (detection methods) } \\
\hline \multirow[t]{2}{*}{ RSV } & \multicolumn{4}{|c|}{ Coronavirus } & \multirow[t]{2}{*}{ HBoV } & Polyomavirus \\
\hline & $\begin{array}{l}\mathrm{HCoV} \\
229 \mathrm{E}\end{array}$ & $\begin{array}{l}\mathrm{HCoV} \\
\mathrm{OC} 43\end{array}$ & $\begin{array}{l}\mathrm{HCoV} \\
\mathrm{NL} 63\end{array}$ & $\begin{array}{l}\text { HCoV } \\
\text { HKU1 }\end{array}$ & & $\overline{\text { WUPyV KIPyV }}$ \\
\hline
\end{tabular}

X(a) pediatric (30, ventilated
and with bronchiolitis)

$70 \%$ rates of co-infection RSV-hMPV in a cohort of infants with bronchiolitis, suggesting that dual infection may predispose for a more severe disease.

$(\mathrm{d})$

\begin{tabular}{lllll}
\hline$X(a)$ & $X(a)$ & $X(a)$ & $X(a)$ & $X(a)$
\end{tabular}

X(a)

X(a)

$\overline{x(b)}$

(d) children $<2$ years $(63)$ with RTD
17,5\% hMPV positive, 23\% RSV positive, $4.7 \%$ hMPV-RSV coinfections. Similar symptoms between

children $<5$ years $(688)$ $8 \%$ hMPV positive samples negative for RSV, PIV Flu $A$ and $B, A D V$

pediatric (56) with
acute bronchiolitis

children requiring intensive support (85)

$<2$-year-old infants with bronchiolitis(196)

pediatric (30, mean age 10 weeks, ventilated and with bronchiolitis)

589 children hospitalized with respiratory disease $<5$ years

$16 \%$ bronchiolitis is hMPV positive, $67.9 \%$ RSV positive, without clinical d(d)ference.

coinfections with RSV and

hMPV are more severe than infections with either RSV or hMPV alone in young children hMPV and RSV co-infection is associated with increased disease severity

No virus co-infection between RSV and hMPV in a cohort of infants with bronchiolitis the second leading cause of RTD after RSV, $30 \%$ of the hMPV+ and RSV+ children.
$8.5 \%$ rates of hMPV infections, cases are hMPV-RSV coinfections. The duration of hospitalization and requirement for supplemental oxygen were increased in case of hMPV-RSV coinfections

\begin{tabular}{|c|c|c|c|c|c|c|c|}
\hline$\overline{X(a)}$ & & & & & & $\begin{array}{l}46 \text { children with mild to } \\
\text { severe RSV disease } \\
\text { (PIV, fluA and B, } \\
\text { ADVnegative) }\end{array}$ & $\begin{array}{l}\text { hMPV did not contribute } \\
\text { to the severity of RSV disease }\end{array}$ \\
\hline$X(a)$ & $X(a)$ & $X(a)$ & $X(a)$ & $X(a)$ & $X(a)$ & $\begin{array}{l}322 \text { infant patients with } \\
\text { acute respiratory disease }\end{array}$ & $\begin{array}{l}\text { RSV-hMPVs co-infections were } \\
\text { observed in less severe } \\
\text { respiratory disease when } \\
\text { compared to RSV } \\
\text { mono-infections }\end{array}$ \\
\hline (d) & $X(a)$ & $X(a)$ & $X(b)$ & & & $\begin{array}{l}\text { hospitalized with fever } \\
\text { and acute respiratory } \\
\text { symptoms (587) }\end{array}$ & $\begin{array}{l}\text { 4.4\% HCoV infections. } \\
\text { HCoV-NL63 can present as } \\
\text { croup, asthma exacerbation, } \\
\text { febrile seizures, and high fever }\end{array}$ \\
\hline$\overline{X(a)}$ & & & $X(b)$ & & & $\begin{array}{l}\text { children }<3 \text { years with } \\
\text { LRTIs (940) }\end{array}$ & $\begin{array}{l}\text { HCoV-NL63 RNA was detected } \\
\text { in 5.2\% of cases; } 43 \% \text { of the } \\
\text { HCoV-NL63-positive patients } \\
\text { with high viral load and } \\
\text { absence of co-infection } \\
\text { suffered from croup. Most }\end{array}$ \\
\hline
\end{tabular}




\begin{tabular}{|c|c|c|c|c|c|c|}
\hline & & & & & & $\begin{array}{l}\text { co-infections were with } \\
\text { RSV-A HCoV-NL63 co-infection } \\
\text { with RSV-A occurred mainly } \\
\text { in hospitalised patients in } \\
\text { contrast to HCoV-NL63 } \\
\text { co-infections with PIV3 that } \\
\text { were exclusively present in } \\
\text { the outpatient group. Lower } \\
\text { HCoV-NL63 viral load in } \\
\text { patients coinfected with } \\
\text { RSV or PIV3 than in patients } \\
\text { infected with HCoV-NL63 alone }\end{array}$ \\
\hline & $X(b)$ & $X(b)$ & $X(b)$ & $X(b)$ & $\begin{array}{l}1156 \text { patients with } \\
\text { pneumonia, } 513 \text { outpatients, } \\
281 \text { controls }\end{array}$ & $\begin{array}{l}1.8 \% \text { of patients with } \\
\text { pneumonia, } 2.3 \% \text { of } \\
\text { outpatients and } 2.1 \% \text { of } \\
\text { controls had HCoV infections. } \\
\text { In control patients, infection } \\
\text { with any HCoV type or with } \\
\text { all types combined was not } \\
\text { associated with pneumonia }\end{array}$ \\
\hline \multirow[t]{2}{*}{$\overline{X(a)}$} & $X(b)$ & $X(b)$ & $X(b)$ & $X(b)$ & $\begin{array}{l}1043 \text { pediatric ( } 0-19 \text { years old) } \\
\text { respiratory specimens }\end{array}$ & $\begin{array}{l}\text { CoVs were detected in } 6.3 \% \\
\text { of specimens. } 45.5 \% \\
\text { CoV-positive specimens } \\
\text { also had another respiratory } \\
\text { virus detected, most commonly } \\
\text { RSV (67\%). CoV subtypes NL63 } \\
\text { and HKU1 accounted for the } \\
\text { majority of CoVs detected. }\end{array}$ \\
\hline & & & $X(a)$ & & $\begin{array}{l}\text { hospitalized adult patients } \\
\text { (433, mean age } 56 \text { years) }\end{array}$ & $\begin{array}{l}\text { 2\% Hcov NL63 positive, 33\% } \\
\text { coinfected NL63-HRV, 10\% } \\
\text { coinfected NL63-ADV }\end{array}$ \\
\hline $\bar{x}$ & & & $X(b)$ & & $\begin{array}{l}539 \text { children }<15 \text { years } \\
\text { with respiratory disease }\end{array}$ & $\begin{array}{l}\text { 1.3\% HCoV NL63 positive, } \\
43 \% \text { of HCoV infection are } \\
\text { coinfections (RSV, ADV, hMPV) }\end{array}$ \\
\hline$\overline{x(b)}$ & $X(b)$ & $X(b)$ & $X(b)$ & $X(b)$ & 11661 respiratory samples & $\begin{array}{l}\text { high rate of coinfections } \\
\text { observed for HKU1, NL63 } \\
\text { and OC43, mostly with RSV. } \\
\text { No d(d)ferences of HCoV } \\
\text { viral load were observed } \\
\text { between single infection } \\
\text { and RSV coinfection. Detection } \\
\text { of CoVs should not be } \\
\text { interpreted as representing an } \\
\text { incidental infection without } \\
\text { contribute to disease. }\end{array}$ \\
\hline$X(a)$ and $(d)$ & $X(a)$ & $X(a)$ & $X(a)$ & $X(a)$ & $\begin{array}{l}515 \text { children }<5 \text { years old } \\
\text { with LRTIs }\end{array}$ & $\begin{array}{l}\text { The prevalence of HboV was } \\
\text { the second (11\%), the first } \\
\text { was RSV ( } 23 \%) \text {. Among HBoV } \\
\text { infections, a high rate (38\%) } \\
\text { was coinfection. }\end{array}$ \\
\hline$(c),(d),(e), X(a)$ & $X(a)$ & $X(a)$ & $X(b),(e)$ & $X(b),(e) \quad X(b),(e)$ & $\begin{array}{l}259 \text { children (median age, } \\
1.6 \text { years) who had been } \\
\text { hospitalized for acute } \\
\text { expiratory wheezing }\end{array}$ & $\begin{array}{l}\text { Acute HBoV infections appears } \\
\text { associated with presence of } \\
\text { viral DNA in the blood as the } \\
\text { HBoV DNA was reported more } \\
\text { prevalent in the patients blood } \\
\text { during the acute symptoms } \\
\text { than after recovery. High load } \\
\text { and viremic HBoV infection } \\
\text { were associated with } \\
\text { respiratory tract symptoms, } \\
\text { while detection of a low viral } \\
\text { load in the nasopharinx alone } \\
\text { has uncertain relevance }\end{array}$ \\
\hline$\overline{X(b)}$ & $x(b)$ & $x(b)$ & $x(b)$ & $X(b)$ & & $\begin{array}{l}\text { HBoV was detected in } 12 \% \text { of } \\
\text { samples. It was the fourth most } \\
\text { common virus in the material }\end{array}$ \\
\hline
\end{tabular}


Table 1 Recent epidemiological papers on respiratory infections and co-infections (Continued)

\begin{tabular}{|c|c|c|c|c|c|c|c|}
\hline & & & & & & & $\begin{array}{l}\text { after RSV (25\%), HRV (17\%) and } \\
\text { hMPV(14\%). Multiple viral } \\
\text { infections were common } \\
\text { and were present in } 78 \% \\
\text { of the samples, more } \\
\text { commonly RSV }\end{array}$ \\
\hline & & & & & $X(b), X(a)$ & $\begin{array}{l}842 \text { patients hospitalized } \\
\text { with respiratory symptoms } \\
\text { (mean age } 22 \text { years) }\end{array}$ & $\begin{array}{l}\text { The prevalence of HBoV } \\
\text { infection was } 3.8 \% \text {. HBoV. } \\
\text { Viral load appears to be } \\
\text { linked to the severity of } \\
\text { the disease. }\end{array}$ \\
\hline$X(a)$ & $X(a)$ & $X(a)$ & $X(a)$ & $X(a)$ & $X(a), X(b),(e)$ & $\begin{array}{l}817 \text { children with } \\
\text { respiratory tract } \\
\text { infection }\end{array}$ & $\begin{array}{l}\text { HBoV was ident(d)ied in } \\
12 \% \text { of samples. Co-infection } \\
\text { rate with other respiratory } \\
\text { viruses was } 51 \% \text {. HBoV was } \\
\text { found frequently in children } \\
\text { with respiratory tract } \\
\text { symptoms associated with } \\
\text { other viruses, and persisted } \\
\text { in the respiratory tract, in } \\
\text { serum and urine. The } \\
\text { presence of IgM was } \\
\text { significantly more prevalent } \\
\text { in viremic patients and those } \\
\text { diagnosed with high load of } \\
\text { HBoV DNAin nasal/throat } \\
\text { swabs }\end{array}$ \\
\hline (e) & & & & & (e) & $\begin{array}{l}124 \text { children with } \\
\text { presumptive pneumonia } \\
<15 \text { years }\end{array}$ & $\begin{array}{l}\text { Mixed infections were found } \\
\text { in } 25 \% \text { of cases. Serological } \\
\text { evidence of acute HBoV } \\
\text { infection was found in } 12 \% \\
\text { of children with pneumonia } \\
\text { and in more than half of } \\
\text { cases with single HBoV } \\
\text { infection.This suggests that } \\
\text { HBoV may be a fairly } \\
\text { common cause of } \\
\text { pneumonia in children }\end{array}$ \\
\hline$X(a)$ & $X(a)$ & $X(a)$ & $X(a)$ & $X(a)$ & $X(a),(e), X(b)$ & $\begin{array}{l}259 \text { weezing children } \\
<15 \text { years, } 115 \text { healthy } \\
\text { adults }\end{array}$ & $\begin{array}{l}\text { Serologically confirmed } \\
\text { primary HBoV infections } \\
\text { detected in symptomatic } \\
\text { children with no signs of } \\
\text { other respiratory virus } \\
\text { infections demonstrate } \\
\text { that HBoV is a cause of } \\
\text { acute wheezing in young } \\
\text { children. Accurate HBoV } \\
\text { diagnosis requires serologic } \\
\text { analysis or PCR of serum, } \\
\text { PCR of NPAs alone is } \\
\text { insufficient. HBoV is the } \\
\text { most probable cause of } \\
\text { respiratory tract disease } \\
\text { (d) the patients has single } \\
\text { infection, a high viral load } \\
\text { in NPA nasopharyngeal } \\
\text { aspirates and viremia }\end{array}$ \\
\hline$X(a)$ & $X(a)$ & $X(a)$ & $X(a)$ & $X(a)$ & $X(b)$ & $\begin{array}{l}119 \text { children } \\
\text { attending daycare }\end{array}$ & $\begin{array}{l}28 \% \text { tested positive for } \\
\text { HBoV. HBoV was detected } \\
\text { significantly more often } \\
\text { than any of the } 14 \\
\text { respiratory viruses but HRVs. } \\
\text { HboV DNA can persist for } \\
\text { several months in the } \\
\text { respiratory tract }\end{array}$ \\
\hline
\end{tabular}


Table 1 Recent epidemiological papers on respiratory infections and co-infections (Continued)

\begin{tabular}{|c|c|c|c|c|c|c|c|c|c|}
\hline$X(a)$ & & & $X(a)$ & $X(a)$ & $X(a)$ & & & $\begin{array}{l}813 \text { children }<14 \text { years } \\
\text { with acute lower } \\
\text { respiratory tract } \\
\text { infections }\end{array}$ & $\begin{array}{l}\text { The most frequently } \\
\text { detected virus was } \\
\text { RSV (40.\%), followed } \\
\text { by HRV (20\%), HBoV } \\
(11.5 \%), \text { PIV1-3 (8\%), } \\
\text { AdV (7.5\%), FluA (7\%), } \\
\text { HMPV (6.\%), NL63 (4\%), } \\
\text { HKU1 (2.\%) and FluB } \\
\text { (0.98\%). Of the HCoV-HKU1 } \\
\text { and HCoV-NL63-positive } \\
\text { samples, 74\% were } \\
\text { co-infected with at least } \\
\text { another virus, most } \\
\text { commonly HRV and RSV. }\end{array}$ \\
\hline \multirow[t]{2}{*}{$X(a)$} & $X(a)$ & $X(a)$ & $X(a)$ & $X(a)$ & $X(a)$ & & & $\begin{array}{l}592 \text { children with } \\
\text { radiographically } \\
\text { confirmed pneumonia }\end{array}$ & $\begin{array}{l}\text { HBoV was the most } \\
\text { frequently detected } \\
\text { virus(10\%) after RSV } \\
(31 \%) \text { and HRV (24\%) }\end{array}$ \\
\hline & $X(a)$ & $X(a)$ & $X(a)$ & $X(a)$ & & $X(b)$ & & $\begin{array}{l}\text { 2,263 samples from } \\
\text { children }<4 \text { years of } \\
\text { age and } 374 \text { from } \\
\text { children }>4 \text { years of } \\
\text { age for routine } \\
\text { respiratory virus } \\
\text { detection }\end{array}$ & $\begin{array}{l}2.7 \% \text { samples positive } \\
\text { for WU polyomavirus } \\
\text { and } 71 \% \text { coinfected } \\
\text { with other viruses. } \\
\text { WU polyomavirus was } \\
\text { the sole virus detected } \\
\text { in } 20 \text { specimens from } \\
\text { patients with respiratory } \\
\text { illness, which suggests } \\
\text { that it may be a respiratory } \\
\text { pathogen. Repeated } \\
\text { identification of WU } \\
\text { polyomavirus in the } \\
\text { same patients suggests } \\
\text { that it may persistently } \\
\text { infect humans }\end{array}$ \\
\hline$X(a)$ & $X(a)$ & $X(a)$ & $X(a)$ & $X(a)$ & $X(a)$ & $X(a)$ & & $\begin{array}{l}486 \text { children with } \\
\text { acute lower respiratory } \\
\text { tract, } 72 \text { asymptomatic } \\
\text { children }<6 \text { years }\end{array}$ & $\begin{array}{l}\text { WUPy } V \text { was detected } \\
\text { in } 7 \% \text { children with } \\
\text { LARD, } 4.2 \% \text { of } \\
\text { asymptomatic children } \\
\text { and as coinfection with } \\
\text { other respiratory viruses } \\
\text { in } 67.6 \% \text {. Although WUPyV } \\
\text { was frequently detected, } \\
\text { its clinical role has not } \\
\text { been distinguished from } \\
\text { that of coinfecting viruses }\end{array}$ \\
\hline \multirow[t]{3}{*}{$\overline{X(a)}$} & $X(a)$ & $X(a)$ & $X(a)$ & $X(a)$ & $X(b)$ & $X(b)$ & $X(b)$ & $\begin{array}{l}2866 \text { respiratory sample } \\
\text { from people with acute } \\
\text { respiratory diseases } \\
\text { (mean age } 9.2 \text { years) }\end{array}$ & $\begin{array}{l}\text { KIV and WUV were found } \\
\text { at a prevalence of } 2.6 \% \\
\text { and } 4.5 \% \text {, respectively. } \\
\text { Level of co-infection of KIV } \\
\text { or WUV with other viruses } \\
\text { was } 74.7 \% \text { and } 79.7 \% \text {, } \\
\text { respectively. It is not } \\
\text { possible to prove a causal } \\
\text { relationship between the } \\
\text { detection of KIV and WUV } \\
\text { and respiratory disease from } \\
\text { these findings }\end{array}$ \\
\hline & & & & & $X(a)$ & $X(a)$ & & $\begin{array}{l}\text { 1,326 hospitalized } \\
\text { children with acute } \\
\text { respiratory diseases }\end{array}$ & $\begin{array}{l}\text { 4.9\% positive WUPyV. 56\% } \\
\text { were co-infections with } \\
\text { other viruses (ADV, fluA, } \\
\text { hBoV and RSV). }\end{array}$ \\
\hline & & & & & & $X(b)$ & $X(b)$ & $\begin{array}{l}153 \mathrm{HIV}-1 \text {-infected } \\
\text { patients (mean age } \\
42 \text { years), } 130 \text { controls }\end{array}$ & $\begin{array}{l}\text { 2.6\% KIPyV positive and } 4.6 \% \\
\text { WUPyV positive among } \\
\text { HIV-1-infected patients } \\
\text { compared with } 3.1 \% \text { KIPyV } \\
\text { positive and 0,8\% WUPyV } \\
\text { positive in blood donors. }\end{array}$ \\
\hline
\end{tabular}


Table 1 Recent epidemiological papers on respiratory infections and co-infections (Continued)

\begin{tabular}{|c|c|c|c|c|c|c|c|c|c|}
\hline & & & & & & & & & $\begin{array}{l}\text { No association found between } \\
\text { CD4+ cell counts in HIV-1 } \\
\text { positive patients and infection } \\
\text { with KIPyV or WUPyV }\end{array}$ \\
\hline$X(a)$ & $X(a)$ & $X(a)$ & $X(a)$ & $X(a)$ & $X(a)$ & $X(a)$ & $X(a)$ & $\begin{array}{l}31 \text { asymptomatic } \\
\text { adulthematopoietic } \\
\text { stem cell transplant } \\
\text { recipients; } 486 \text { children } \\
\text { with acute respiratory } \\
\text { disease }<2 \text { years }\end{array}$ & $\begin{array}{l}0.79 \% \text { KIPyV, } 0.79 \% \text { WuPyV } \\
\text { positive among transplant } \\
\text { recipients; } 1.4 \% \text { KIPyV and } 0.2 \% \\
\text { WUPyV in children. WU/KIPyVs } \\
\text { have a low pathogenic } \\
\text { potential in young children. } \\
\text { Brief and asymptomatic } \\
\text { infection can occur in } \\
\text { hematopoietic transplant } \\
\text { recipients. }\end{array}$ \\
\hline$X(b)$ & & & & & $x(b)$ & $X(a)$ & & $\begin{array}{l}771 \text { children with acute } \\
\text { respiratory tract infection } \\
\text { and } 82 \text { samples from } \\
\text { healthy subjects }\end{array}$ & $\begin{array}{l}\text { In most of infected children } \\
\text { single WUPyV infection was } \\
\text { detected.It suggests that the } \\
\text { newly described polyomavirus } \\
\text { can cause acute respiratory } \\
\text { tract infection }\end{array}$ \\
\hline$X(a)$ & $X(a)$ & $X(a)$ & $X(a)$ & $X(a)$ & & $X(b)$ & $X(b)$ & $\begin{array}{l}\text { pediatric hematology } \\
\text { or oncology patients } \\
\text { and immunocompetent } \\
\text { controls with acute } \\
\text { respiratory illnesses }\end{array}$ & $\begin{array}{l}\text { Prevalence of WUPyV and } \\
\text { KIPyV is similar in hematology/ } \\
\text { oncology patients ( } 3 \% \text { and } \\
5.6 \% \text {, respectively) compared } \\
\text { with the general pediatric } \\
\text { population (5\%and 2.3, } \\
\text { respectively). High co-detection } \\
\text { rates with other viruses } \\
\text { (RSV and HRV) in both groups. } \\
\text { Higher viral loads for KIPyV } \\
\text { (but not for WUPyV) in the } \\
\text { immunocompromised group } \\
\text { was detected and infection } \\
\text { with either virus occurred in } \\
\text { older children compared with } \\
\text { controls, which may suggest } \\
\text { viral-reactivation }\end{array}$ \\
\hline (d) & $X(a)$ & $X(a)$ & $X(a)$ & $X(a)$ & & & & $\begin{array}{l}203 \text { nasopharyngeal } \\
\text { aspirates (NPAs), } \\
\text { negative for common } \\
\text { respiratory viruses from } \\
\text { hospitalized children }\end{array}$ & $\begin{array}{l}\text { HRV-C is an important cause of } \\
\text { febrile wheeze and asthmatic } \\
\text { exacerbations in children } \\
\text { requiring hospitalization. } \\
\text { No clear clinical difference } \\
\text { has been noted between } \\
\text { single or mixed HRV-C } \\
\text { infections }\end{array}$ \\
\hline$X(a)$ & & & & & $X(a)$ & & & $\begin{array}{l}4,173 \text { respiratory } \\
\text { samples for routine } \\
\text { respiratory virus } \\
\text { detection }\end{array}$ & $\begin{array}{l}\text { High rate of coinfections, } \\
\text { ow frequency of detection } \\
\text { and lack of clear disease } \\
\text { associations indicate that } \\
\text { HPeV1 and }-6 \text { are not } \\
\text { major pathogens in } \\
\text { individuals presenting } \\
\text { with respiratory disease }\end{array}$ \\
\hline$X(a)$ & $X(a)$ & $X(a)$ & $X(a)$ & $X(a)$ & $X(a)$ & & & $\begin{array}{l}406 \text { children< } 14 \text { years } \\
\text { with RTI }\end{array}$ & $\begin{array}{l}\text { 13\% HRV positive ( } 22 \% \text { HRV-A, } \\
12 \% \text { HRV-B, } 19 \% \text { HRV-C). } \\
\text { Monoinfection was observed } \\
\text { in more than half of cases, } \\
\text { HRV-C is an important cause } \\
\text { of RTIs in children. Patients } \\
\text { infected with HRV-C may } \\
\text { exhibit different clinical } \\
\text { features from patients infected } \\
\text { with HRV-A/B }\end{array}$ \\
\hline & & & & & & & & $\begin{array}{l}1052 \text { hospitalized } \\
\text { children< } 5 \text { years } \\
\text { with acute respiratory } \\
\text { illness }\end{array}$ & $\begin{array}{l}\text { HRVCs were detected in } 7 \% \text { of } \\
\text { children hospitalized for fever } \\
\text { or respiratory conditions and } \\
\text { constituted almost half of all }\end{array}$ \\
\hline
\end{tabular}




\begin{tabular}{|c|c|c|c|c|c|c|c|c|c|}
\hline & & & & & & & & & $\begin{array}{l}\text { HRVs-associated } \\
\text { hospitalizations, suggesting } \\
\text { that this novel group causes } \\
\text { a substantial burden of } \\
\text { pediatric disease }\end{array}$ \\
\hline & & & & & & & & $\begin{array}{l}3,800 \text { children aged } \\
2 \text { to } 13 \text { years with } \\
\text { respiratory illness }\end{array}$ & $\begin{array}{l}\text { EV109 isolates were then } \\
\text { detected in } 1.6 \% \text { of } \\
\text { respiratory samples of } \\
\text { children with influenza } \\
\text { like illness (ILI) and } \\
\text { recognized to have a } \\
\text { pathogenetic role in } \\
\text { the illness }\end{array}$ \\
\hline$X(a)$ & $X(a)$ & $X(a)$ & $X(a)$ & $X(a)$ & $X(a)$ & $X(a)$ & $X(a)$ & $\begin{array}{l}1149 \text { nasopharingeal } \\
\text { aspirates }\end{array}$ & $\begin{array}{l}\text { HEV109 infection may be } \\
\text { associated to ARDs both } \\
\text { in infants and in } \\
\text { hematopoietic stem } \\
\text { cell transplantation } \\
\text { recipients }\end{array}$ \\
\hline$X(a)$ & $X(a)$ & $X(a)$ & X(a) & $X(a)$ & X(a) & $X(a)$ & $X(a)$ & $\begin{array}{l}3,525 \text { patients with } \\
\text { respiratory syndrome }\end{array}$ & $\begin{array}{l}\text { The prevalence of HpeV } \\
\text { is } 0.4 \% \text {. The most } \\
\text { commonly identified } \\
\text { HPeVs were HpeV1(58\%) } \\
\text { and HpeV3 (37\%). Although } \\
\text { not circulating at high } \\
\text { frequency and unlikely to } \\
\text { cause respiratory syndrome, } \\
\text { HPeV was associated with } \\
\text { severe clinical syndromes in } \\
\text { a minority of newborns. } \\
\text { The frequent association } \\
\text { of HPeV with other respiratory } \\
\text { viruses may indicate a less } \\
\text { pathogenic role for HPeV } \\
\text { compared to the other viruses }\end{array}$ \\
\hline \multirow[t]{2}{*}{$X(a)$} & $X(a)$ & & & & $X(a)$ & & & $\begin{array}{l}56 \text { adults and } 39 \text { children } \\
\text { visited for influenza-like } \\
\text { illnesses }\end{array}$ & $\begin{array}{l}31 \% \text { of H1N1 infections, } 16 \% \\
\text { coinfected with HRV (60\%) } \\
\text { and RSV, CoV229E, HBoV (20\%). } \\
\text { No difference in disease } \\
\text { severity between single and } \\
\text { mixed infections }\end{array}$ \\
\hline & & & & & & & & $\begin{array}{l}\text { pediatric ( } 2121, \text { mean } \\
\text { age } 3.8 \text { years) }\end{array}$ & $\begin{array}{l}\text { The presence of HRV reduce } \\
\text { the risk of } \mathrm{H} 1 \mathrm{~N} 1 \text { infection. }\end{array}$ \\
\hline$X(a)$ & $X(a)$ & $X(a)$ & $X(a)$ & & & & & $\begin{array}{l}\text { in adult and paediatric } \\
\text { patients with Influenza-like } \\
\text { illness (413) }\end{array}$ & $\begin{array}{l}\text { 16\% of H1N1 infections, 19\% of } \\
\text { them were co-infections } \\
\text { (mainly HRV). Among } 50 \% \text { of } \\
\text { non-H1N1 infections were } \\
\text { HRV infections and increase } \\
\text { of H1N1 cases was associated } \\
\text { with rapid HRV infection decline }\end{array}$ \\
\hline
\end{tabular}

(a) qualitative molecular detection; (b) quantitative molecular detection; (c) cell culture; (d) Immune Fluorescence; (e) serology.

The pathogens analyzed and the methods used for detection as well as the population characteristics and the main conclusions are reported. The principal pathogen under evaluation is indicated in bold. Flu=influenza virus; $\mathrm{HRV}=$ human rhinovirus; $\mathrm{HEV}=\mathrm{human}$ enterovirus; $\mathrm{HpeV}=$ human parechovirus; $\mathrm{PIV}=$ parainfluenza virus; $\mathrm{hMPV}=$ human metapneumovirus; $\mathrm{ADV}=$ adenovirus; $\mathrm{RSV}=$ respiratory syncytial virus.

child with acute respiratory distress attending an emergency department in Germany [89]. Don et colleagues [76] found serological evidence of an acute $\mathrm{HBoV}$ infection in $12 \%$ of children with pneumonia and in more than half of these cases with single $\mathrm{HBoV}$ infection. In most cases a significant rise in IgG antibodies between paired sera was found in children admitted to hospital for radiologically confirmed pneumonia. IgM antibodies were also detected in all but one patient. This study suggests that $\mathrm{HBoV}$ may be a fairly common cause of pneumonia in children Table 1.

\section{$\mathrm{KI}$ and WU Polyomaviruses}

Two new polyomaviruses were identified in 2007 in respiratory tract samples following large scale molecular screening using high throughput DNA sequencing of random clones [5,7] and have been named after the institutes where they were found: KI (Karolinska Institute) 
polyomavirus (KIPyV) and WU (Washington University) polyomavirus (WUPyV). Data on seroprevalence indicate that infection is widespread ranging from 54.1 and $67 \%$ for KI and from $66.4 \%$ and $89 \%$ for WU in North American and German blood donors [90,91]. Since their first identification, KI and WU viral sequences have been confirmed worldwide in respiratory samples from children with respiratory tract disease ranging from $0.2 \%$ to $2.7 \%$ and from 1.1 to 7\%, respectively [91-97]. However WUPyV and KIPyV were found at similar frequencies in control groups without respiratory diseases so the link between these polyomaviruses and acute respiratory diseases remains speculative $[94,96,98]$.

Careful analysis is complicated by high co-infection rates with other well-characterized viral respiratory pathogens. A co-detection rate of $74 \%$ has been observed for KIPyV and rates ranging from 68 to $79 \%$ for WUPyV $[94,95,97]$. Therefore, in a recent study in Southern China, hospitalized children with WUPyV infection displayed predominantly cough, moderate fever, and wheezing, but were also diagnosed with pneumonia, bronchiolitis, upper respiratory tract infections and bronchitis. As in most of infected children a single WUPyV infection was detected, it was suggested that the newly described polyomavirus can cause acute respiratory tract infection with atypical symptoms, including severe complications [99]. Nevertheless these data have to be confirmed in further studies.

The presence of WUPyV and KIPyV in samples from children but not from immunocompetent adults suffering from LRTIs suggests that these viruses primarily infect the young population [100]. A correlation between immunosuppression and reactivation of the two novel polyomaviruses has been suggested in immunocompromised patients [101] and in AIDS patients at the molecular level [102], but no evidence of a role of these viruses as opportunistic pathogens has been given.

Overall, these data support the hypothesis that, in analogy with BK and JC polyomaviruses, KIPyV and WUPyV can establish persistent infection, and that virus replication may increase in immunocompromised hosts. However, in a recent study on immunocompetent and immunocompromised adult patients, real-time PCR detected KIPyV and WUPyV in $2.6 \%$ and $4.6 \%$ of HIV1 -infected patients respectively and in $3.1 \%$ and $0.8 \%$ of blood donors respectively, while no association was found between CD4+ cell counts in HIV-1 positive patients and infection with KIPyV or WUPyV [103].

KIPyV and WUPyV are also incidentally detected in adults with community acquired pneumonia, in immunocompromised hosts, and in patients with lung cancer; they are more often found in patients suffering an underlying medical condition and coinfections with $\mathrm{KIPyV}$ and WUPyV with other respiratory viruses are common [92,103,104]. A recent study evaluating the prevalence and viral load of WUPyV and KIPyV in respiratory samples from immunocompromised and immunocompetent children showed that the prevalence of WUPyV and KIPyV is similar in hematology/oncology patients compared with that of the general pediatric population [105]. High co-detection rates with other respiratory viruses, mainly RSV and enterovirus or rhinovirus, were found for WUPyV and KIPyV in both groups, in analogy with previous reports. However, higher viral loads for KIPyV in the immunocompromised group were detected, suggesting that there may be an increased replication of this virus in this population.

A similar association was not observed for WUPyV. Furthermore, in the immunocompromised group, infection with either virus occurred in older children compared with controls, which may indicate viral-reactivation Table 1.

\section{Rhinovirus, Enterovirus and Parechovirus Rhinoviruses}

HRVs are currently classified in the Picornaviridae family, genus Enterovirus, that includes 3 species: HRV-A, HRV-B, and HRV-C. Within each species there are multiple HRVs designated as "serotypes", "types", or "strains". Several recent epidemiological studies suggest that HRV-A and HRV-C are the predominant species associated with acute respiratory illnesses in hospitalized children and adults, compared to HRV-B which are rarely detected [106].

The new HRV lineage designated HRV-C has been identified using molecular methods and associated with severe clinical presentations in infants and immunocompromised adults. Symptoms of patients infected with this new strain were mainly bronchiolitis, wheezing, and asthmatic exacerbation in cases from Australia and Hong Kong, which peaked in fall and winter whereas in New York the new rhinovirus genotype was detected in cases of influenza like illness (ILI) that were clustered within an 8-week period from October to December [62,107,108]. A recent study describes a clinical case of severe respiratory and pericardial disease in an infant infected by HRV-C suggesting tha viral tropism is not strictly restricted to the respiratory tract [109]. A study focusing on the global distribution of novel rhinovirus indicates its association with community outbreaks and pediatric respiratory disease also in Africa and in symptomatic subjects living in remote locations having limited contacts with other human populations. Moreover evidence for a role of HRV-C in lower respiratory tract disease and febrile wheeze in infants and asthma exacerbations in older children was reported [110-114]. Recent studies making comparisons between HRVs species, found the HRV Cs more so than As or Bs as the major contributors to febrile wheeze and asthma exacerbation in infants and children, respectively. However, the 
severity of clinical manifestations for HRV-C is comparable to that for HRV-A in children with communityacquired pneumonia [115]. In HRV $C$ studies so far, no clear clinical difference has been noted between patients with single or mixed HRV-C infection $[111,113,116]$. In a study, monoinfection was observed in more than half of cases and was more common than RSV monoinfection in patients with upper RTD, however the duration of hospitalizations was not significantly different between the HRV-C monoinfection group, HRV-A or HRV-B monoinfection group and RSV group suggesting that HRV-C is an important etiological factor in children with RTI [117]. Most HRV-C co-detections are with RSV [113,117-119], however in a large study HRVs were statistically the least likely virus of 17 examined to be associated with coinfections [120] Table 1.

\section{Enteroviruses}

A novel HEV (EV104) genotype was first identified in Switzerland in 2010 from respiratory samples collected during 2004-2007 in 8 children with respiratory signs and symptoms and acute otitis media [121]. In a following epidemiologic study conducted in Italy, five strains of the new EV104 genotype were detected in patients with respiratory diseases [122]. Patients were aged 2 to 62 years and most had underlying diseases; in immunocompetent patients EV104 was associated with chronic rhinopharyngytis, whereas in immunocompromised patients with symptoms of acute respiratory tract infection including wheezing, fever and rhinorrhea. Only in one out of 5 patients a coinfecting virus was detected.

EV109 was first discovered from a case of acute respiratory illness in a Nicaraguan child in September 2010; EV109 isolates were then detected in $1.6 \%$ of respiratory samples of children with influenza like illness (ILI) in Managua, and recognized to have a pathogenetic role in the illness [2]. After this characterization, a species $\mathrm{C}$ of HEV distantly related to EV109 was retrieved from a rectal swab of a deceased patient during an outbreak of flaccid paralysis in Congo; in this sample poliovirus and other neurologic, enteric and respiratory viral pathogens were not detected [123]. The global distribution of EV 109 is currently unknown and only a few studies have been performed yet to evaluate epidemiological features of this infection. [124,125] To date the pathogenic role of these new enterovirus strains has still to be defined in larger clinical and epidemiological surveys Table 1.

\section{Parechoviruses}

There are fourteen known $\mathrm{HPeV}$ genotypes that were isolated mainly in young children [126-134]

Two recent studies have investigated the involvement of $\mathrm{HPeVs}$ in respiratory diseases reporting a low frequency of detection and a lack of clear disease association [135,136]. Both studies detected $\mathrm{HPeV}$ infections mostly in children below 5 years and the most commonly identified parechoviruses were $\mathrm{HPeV} 1$ and $\mathrm{HPeV} 3$, while $\mathrm{HPeV} 4$, $\mathrm{HPeV} 5$ and HPeV 6 were detected in a minority of cases. However, in addition to a low HPeVs prevalence in respiratory samples, a high rate of co-infection with other respiratory viruses was observed in $\mathrm{HPeV}$ positive samples, making it difficult to define a pathogenic role of these new $\mathrm{HPeV}$ genotypes in child respiratory infections.

\section{Pandemic A/H1N1v influenza 2009}

In March 2009, a novel reassortant influenza strain (A/ H1N1v) was discovered in Mexico as an infective agent in humans [137,138]. From April 15 through May 5, 2009, a total of 642 confirmed cases of human infection with the outbreak strain of H1N1v were identified in 41 states in the USA $[139,140]$. Of the patients with confirmed infection, $9 \%$ required hospitalization. The age of hospitalized patients ranged from 19 months to 51 years and among the hospitalized patients for whom data were available, $18 \%$ were children under the age of 5 years. Multiple reports have described the clinical features of infection with this novel virus, which are similar or milder to those of seasonal influenza, [141,142]. The spectrum of clinical presentation varies from self limiting respiratory tract illness in most cases, to primary viral pneumonia resulting in respiratory failure, acute respiratory distress, multi-organ failure and death, most of them occurring in patients with underlying medical conditions [142].

During the A/H1N1v flu wave, due mainly to the lack of cross-neutralizing anti-influenza antibodies [143,144] or the presence of co-morbidities, more children and younger adults were infected by the pandemic flu strain and had serious disease than in the seasonal epidemic. For this reason they were identified as a particular risk group, together with pregnant women $[145,146]$. Young children presented a higher attack rate than older adults and a greater mortality rate than previously observed with classical seasonal flu $[147,148]$. In a study conducted in England from June 2009 to March 2010, a childhood mortality rate of 6 per million population was reported. The rate was highest for children less than 1 year and with severe pre-existing disorders [149]. Similar data are reported in other studies highlighting that most severe cases occurred in children with known comorbidities [150-153].

The occurrence of co-infection with influenza A H1N1v and other respiratory viruses has been reported in few studies. In a study conducted in France and aimed at investigating respiratory pathogens involved in ILI during the early weeks of the 2009-29010 H1N1v diffusion, 
$19 \%$ of samples positive for H1N1v were also positive for other respiratory pathogens. In mixed infections, HRV was the more frequent co-pathogen being detected in $13.2 \%$ of all samples positive for H1N1v [154]. However, HRV infections represented nearly half of non-H1N1v viral infections and the increase of $\mathrm{H} 1 \mathrm{~N} 1 \mathrm{v}$ positive cases was associated with a rapid decline of HRV infections. In addition, the frequency of virus co-infection was slightly but not significantly higher in samples positive for H1N1v as compared with samples positive for other respiratory pathogens and viral mixed infection both with H1N1v and other viruses was not associated with a different clinical presentation. Similar co-infection data are reported in a prospective study evaluating a combination of two RT-PCR DNA microarray systems in virological routine diagnosis of ILI [155]. In both studies conducted in France, in the same H1N1v early pandemic period, few RSV infections were reported compared with epidemiological data in the same period of the last four years. The delayed and reduced circulation of RSV observed in 2009-10 compared with 2008-09 suggests that the early circulation of the 2009 pandemic influenza $A(\mathrm{H} 1 \mathrm{~N} 1)$ viruses had an impact on the RSV epidemic [156]. A significant inverse relationship between HRV and A H1N1 pandemic virus was also reported, suggesting that the presence of HRV reduces the risk of infection by the H1N1 virus and thus, indirectly, the spread of the virus [156] Table 1.

\section{Orphan viruses}

Torque tenovirus (TTV), is classified in the new genus Anellovirus [157]. TTV produces long-lasting (possibly life-long) viremia in about $80 \%$ of apparently healthy individuals of all ages and living in different countries [158]. Although no evidence was obtained that TTV is a direct cause of acute respiratory diseases, it was observed that average viral loads are considerably higher in children with bronchopneumonia than in children with milder illnesses, regardless of the presence of common respiratory viruses [159]. Further studies could not confirm the association, but documented a link between TTV infection in children and asthma, suggesting that TTV might be a contributing factor in the lung impairment caused by this condition [160]. Finally, it was documented that TTV is able to infect respiratory ciliated cells and that these cells are potentially able to support viral replication [161]. Far from being conclusive, the data suggest that these viruses may replicate efficiently in the respiratory tract of children with and without acute respiratory infections by other respiratory viruses, and that although TTV does not have a clear pathogenic role in acute respiratory diseases, it may influence the clinical presentation of the disease.

\section{Conclusions}

Over the past 10 years, advances in scientific knowledge and the availability of new technologies have deeply changed our views in the field of respiratory viral infections. In particular, the identification of new viruses or viral strains has allowed to better define the viral etiology in many respiratory diseases where the viral pathogen was only hypothesized or suspected.

Molecular virological diagnosis has thus gained an increasing importance with the development of novel molecular assays, in some cases able to detect many respiratory viruses simultaneously.

Nevertheless, despite the availability of novel diagnostic assays, data are still controversial regarding the role of coinfection in a more severe clinical outcome in comparison to single infections.

In this context, even though specific antiviral compounds or vaccines are being developed, the level of accuracy and the associated higher costs of complex molecular assays to highlight the presence of one or more viruses in the same samples, are often considered not to be clinically necessary.

However, some important considerations emphasize the importance of implementing diagnostic approaches that allow the identification of the greatest number of newly identified or emerging viral respiratory pathogens. Firstly, the use of diagnostic assays able to simultaneously detect more respiratory viruses, including the newly identified ones, and in some cases their load, will help to clarify virus-host interactions which are still partially unknown, in particular in hospitalized patients. This will allow to develop appropriate control measures for nosocomial infection containment. Moreover, in many cases respiratory viruses pave the way to severe secondary bacterial infections. Thus the rapid identification of viral pathogens may help to limit disease progression and to plan appropriate monitoring and patient management in defined clinical settings. Furthermore, rapid and reliable screening with large panel of respiratory viruses responsible for upper and lower RTIs is of major epidemiological and clinical interest for monitoring influenza pandemic waves or unexpected respiratory outbreaks.

In addition, in the case of emerging viral strains as well as for enteroviruses, parechovirus or rhinoviruses the subsequent or simultaneous circulation of genetically distinct strains with distinct pathogenic potential, suggests a high risk for repeated pediatric respiratory infections as well as the possibility of genetic recombination within species. In these cases, the continuous development of quantitative assays associated with viral genotyping assays will allow the rapid and valuable etiological diagnosis of enterovirus, parechovirus or rhinovirus childhood infections, helping to prevent both 
nosocomial transmission and to control the emergence of new respiratory strains with unpredictable pathogenic potential.

\section{Competing interests}

The authors declare that they have no competing interests.

\section{Authors' contributions}

MD, FC, MC wrote the manuscript. ERC organized the table. All authors read and approved the final manuscript.

\section{Authors' information}

Maurizia Debiaggi graduated with a first-class degree in Biological Sciences at the University of Pavia in 1984. From 1984 to 1991, following the award of a Research Grant in the area of infectious diseases, she worked in the Department of Microbiology, University of Pavia. In these years she acquired skills in molecular virology and diagnostic microbiology. Since November 1992 she is Researcher at the Department of Clinical and Diagnostic Sciences, Unit of Microbiology, University of Pavia. Her scientific activity has been mainly intent on molecular virology studies; she focused on the molecular epidemiology of emerging viruses such as the novel Human Metapneumovirus, NL-63 and HKU1 coronaviruses and the human Bocavirus. Her teaching activity is currently held in the official courses of Medical Microbiology for medical students as well as for students obtaining their Degree in Medical Biothecnologies at the Medical School of the University of Pavia.

Filippo Canducci graduated in Medicine Cum Laude (Universtà Cattolica, Roma) in 2001. In 2005 he became PhD in Pharmacology, Chemotherapy and Microbiology (University of Trieste). In 2008 he specialized in Microbiology and Virology at the Università Vita-Salute San Raffaele where since 2009 he is Contract Professor in Microbiology. In 2003, he isolated and characterized the SARS Coronavirus strain HSR1 and in 2004 he was awarded by the Carlo Urbani Foundation. Dr Canducci has studied the prevalence and variability of emerging respiratory viruses such as the human Metapneumovirus, the Coronvaviruses NL-63 and HKU1, human Bocavirus and pandemic Influenza A virus. Since 2003 he has studied HIV-1 infection in vitro in vivo by original phenotypic assays. Dr Canducci is now also leading a research group to study the pathogenetic mechanisms of atherosclerosis. In 2010 Dr Canducci was granted the Young Investigators Grant from the Italian Ministry of Health.

Elisa Rita Ceresola graduated cum laude in Biological Sciences at the Università Vita-Salute San Raffaele in 2009. She is currently specializing in Microbiology and Virology in the same University. Elisa Rita Ceresola has focused her research on the epidemiology and molecular variability of emerging respiratory viruses and on optimization of molecular assays to characterize HIV-1 infection in vitro and ex-vivo.

Massimo Clementi is Dean of the Faculty of Medicine and Professor of Microbiology and Virology at the Università Vita-Salute San Raffaele. He is chief of the Laboratory of Microbiology and Virology, Diagnostica e Ricerca San Raffaele, Milan, Italy. He has research interests in the virus-host interplay in the course human immunodeficiency virus and of hepatitis $C$ virus infections, in the microbiology of emerging respiratory infectious diseases, and in infections of immunocompromised patients.

\section{Acknowledgements}

This paper was partially funded by the Italian Ministry of University and Research. Tha Authors are grateful to Dr Shireen Merli for language revision.

\section{Author details}

'Dipartimento di Scienze Clinico-Chirurgiche, Diagnostiche e Pediatriche, sezione di Microbiologia, 20132, Milan, Italy. ${ }^{2}$ Laboratorio di Virologia e Microbiologia, Università degli studi dell'Insubria' San Raffaele, Istituto Scientifico San Raffaele, Via Olgettina 58, 20132, Milan, Italy.

Received: 24 May 2012 Accepted: 18 October 2012 Published: 27 October 2012

\section{References}

1. Woo PC, Lau SK, Chu CM, Chan KH, Tsoi HW, Huang Y, Wong BH, Poon RW, Cai JJ, Luk WK, et al: Characterization and complete genome sequence of a novel coronavirus, coronavirus HKU1, from patients with pneumonia. J Virol 2005, 79:884-895

2. Yozwiak NL, Skewes-Cox P, Gordon A, Saborio S, Kuan G, Balmaseda A, Ganem D, Harris E, DeRisi JL: Human enterovirus 109: a novel interspecies recombinant enterovirus isolated from a case of acute pediatric respiratory illness in Nicaragua. J Virol 2010, 84:9047-9058.

3. van der Hoek L, Pyrc K, Jebbink MF, Vermeulen-Oost W, Berkhout RJ, Wolthers KC: Wertheim-van Dillen PM, Kaandorp J, Spaargaren J, Berkhout B: Identification of a new human coronavirus. Nat Med 2004, 10:368-373.

4. van den Hoogen BG, de Jong JC, Groen J, Kuiken T, de Groot R, Fouchier RA, Osterhaus AD: A newly discovered human pneumovirus isolated from young children with respiratory tract disease. Nat Med 2001, 7:719-724.

5. Allander T, Andreasson K, Gupta S, Bjerkner A, Bogdanovic G, Persson MA, Dalianis T, Ramqvist T, Andersson B: Identification of a third human polyomavirus. J Virol 2007, 81:4130-4136.

6. Allander T, Tammi MT, Eriksson M, Bjerkner A, Tiveljung-Lindell A, Andersson $B$ : Cloning of a human parvovirus by molecular screening of respiratory tract samples. Proc Natl Acad Sci U S A 2005, 102:12891-12896.

7. Gaynor AM, Nissen MD, Whiley DM, Mackay IM, Lambert SB, Wu G, Brennan DC, Storch GA, Sloots TP, Wang D: Identification of a novel polyomavirus from patients with acute respiratory tract infections. PLoS Pathog 2007, 3:e64.

8. Mahony JB: Detection of respiratory viruses by molecular methods. Clin Microbiol Rev 2008, 21:716-747.

9. Jartti L, Langen $H$, Soderlund-Venermo M, Vuorinen T, Ruuskanen $O$, Jartti T: New respiratory viruses and the elderly. Open Respir Med $J$ 2011, 5:61-69.

10. Sloots TP, Whiley DM, Lambert SB, Nissen MD: Emerging respiratory agents: new viruses for old diseases? J Clin Virol 2008, 42:233-243.

11. Tregoning JS, Schwarze J: Respiratory viral infections in infants: causes, clinical symptoms, virology, and immunology. Clin Microbiol Rev 2010, 23:74-98.

12. Jartti $T$, van den Hoogen $B$, Garofalo RP, Osterhaus AD, Ruuskanen O: Metapneumovirus and acute wheezing in children. Lancet 2002 360:1393-1394.

13. Falsey AR, Erdman D, Anderson $\sqcup$, Walsh EE: Human metapneumovirus infections in young and elderly adults. J Infect Dis 2003, 187:785-790.

14. Stockton J, Stephenson I, Fleming D, Zambon M: Human metapneumovirus as a cause of community-acquired respiratory illness. Emerg Infect Dis 2002, 8:897-901

15. Boivin G, Abed Y, Pelletier G, Ruel L, Moisan D, Cote S, Peret TC, Erdman DD, Anderson $L$ J: Virological features and clinical manifestations associated with human metapneumovirus: a new paramyxovirus responsible for acute respiratory-tract infections in all age groups. J Infect Dis 2002, 186:1330-1334.

16. Boivin G, De Serres G, Cote S, Gilca R, Abed Y, Rochette L, Bergeron MG, Dery P: Human metapneumovirus infections in hospitalized children. Emerg Infect Dis 2003, 9:634-640.

17. Wilkesmann A, Schildgen O, Eis-Hubinger AM, Geikowski T, Glatzel T, Lentze MJ, Bode U, Simon A: Human metapneumovirus infections cause similar symptoms and clinical severity as respiratory syncytial virus infections. Eur J Pediatr 2006, 165:467-475.

18. Williams JV, Wang CK, Yang CF, Tollefson SJ, House FS, Heck JM, Chu M, Brown JB, Lintao LD, Quinto JD, et al: The role of human metapneumovirus in upper respiratory tract infections in children: a 20-year experience. J Infect Dis 2006, 193:387-395.

19. van den Hoogen BG, van Doornum GJ, Fockens JC, Cornelissen JJ, Beyer WE, de Groot R, Osterhaus AD, Fouchier RA: Prevalence and clinical symptoms of human metapneumovirus infection in hospitalized patients. J Infect Dis 2003, 188:1571-1577.

20. Sasaki A, Suzuki H, Saito R, Sato M, Sato I, Sano Y, Uchiyama M: Prevalence of human metapneumovirus and influenza virus infections among Japanese children during two successive winters. Pediatr Infect Dis J 2005, 24:905-908.

21. Laham FR, Israele V, Casellas JM, Garcia AM, Lac Prugent CM, Hoffman SJ, Hauer D, Thumar B, Name MI, Pascual A, et al: Differential production of inflammatory cytokines in primary infection with human metapneumovirus and with other common respiratory viruses of infancy. J Infect Dis 2004, 189:2047-2056. 
22. Freymouth F, Vabret A, Legrand L, Eterradossi N, Lafay-Delaire F, Brouard J, Guillois B: Presence of the new human metapneumovirus in French children with bronchiolitis. Pediatr Infect Dis J 2003, 22:92-94.

23. Chano F, Rousseau C, Laferriere C, Couillard M, Charest H: Epidemiological survey of human metapneumovirus infection in a large pediatric tertiary care center. J Clin Microbiol 2005, 43:5520-5525.

24. Kahn JS: Epidemiology of human metapneumovirus. Clin Microbio/ Rev 2006, 19:546-557.

25. Apostoli P, Zicari S, Lo Presti A, Ciccozzi M, Ciotti M, Caruso A, Fiorentini S: Human metapneumovirus-associated hospital admissions over five consecutive epidemic seasons: evidence for alternating circulation of different genotypes. J Med Virol 2011, 84:511-516.

26. Schildgen O, Geikowski T, Glatzel T, Schuster J, Simon A: Frequency of human metapneumovirus in the upper respiratory tract of children with symptoms of an acute otitis media. Eur J Pediatr 2005, 164:400-401.

27. Suzuki A, Watanabe O, Okamoto M, Endo H, Yano H, Suetake M, Nishimura $\mathrm{H}$ : Detection of human metapneumovirus from children with acute otitis media. Pediatr Infect Dis J 2005, 24:655-657.

28. Heikkinen $T$, Osterback R, Peltola $V$, Jartti $T$, Vainionpaa R: Human metapneumovirus infections in children. Emerg Infect Dis 2008, 14:101-106

29. Esposito S: Management of community-acquired pneumonia in infants and children older than 3 months. Clin Infect Dis 2011, 54:884-885.

30. Xepapadaki P, Psarras S, Bossios A, Tsolia M, Gourgiotis D, Liapi-Adamidou G, Constantopoulos AG, Kafetzis D, Papadopoulos NG: Human Metapneumovirus as a causative agent of acute bronchiolitis in infants. J Clin Virol 2004, 30:267-270

31. Viazov S, Ratjen F, Scheidhauer R, Fiedler M, Roggendorf M: High prevalence of human metapneumovirus infection in young children and genetic heterogeneity of the viral isolates. J Clin Microbiol 2003, 41:3043-3045

32. Williams JV, Harris PA, Tollefson SJ, Halburnt-Rush LL, Pingsterhaus JM, Edwards KM, Wright PF, Crowe JE Jr: Human metapneumovirus and lower respiratory tract disease in otherwise healthy infants and children. $N$ Engl J Med 2004, 350:443-450.

33. Esper F, Boucher D, Weibel C, Martinello RA, Kahn JS: Human metapneumovirus infection in the United States: clinical manifestations associated with a newly emerging respiratory infection in children. Pediatrics 2003, 111:1407-1410

34. Canducci F, Debiaggi M, Sampaolo M, Marinozzi MC, Berre S, Terulla C, Gargantini G, Cambieri P, Romero E, Clementi M: Two-year prospective study of single infections and co-infections by respiratory syncytial virus and viruses identified recently in infants with acute respiratory disease. J Med Virol 2008, 80:716-723.

35. van Woensel JB, Bos AP, Lutter R, Rossen JW, Schuurman R: Absence of human metapneumovirus co-infection in cases of severe respiratory syncytial virus infection. Pediatr Pulmonol 2006, 41:872-874.

36. Greensill J, McNamara PS, Dove W, Flanagan B, Smyth RL, Hart CA: Human metapneumovirus in severe respiratory syncytial virus bronchiolitis. Emerg Infect Dis 2003, 9:372-375.

37. Semple MG, Cowell A, Dove W, Greensill J, McNamara PS, Halfhide C, Shears P, Smyth RL, Hart CA: Dual infection of infants by human metapneumovirus and human respiratory syncytial virus is strongly associated with severe bronchiolitis. J Infect Dis 2005, 191:382-386.

38. Foulongne V, Guyon G, Rodiere M, Segondy M: Human metapneumovirus infection in young children hospitalized with respiratory tract disease. Pediatr Infect Dis J 2006, 25:354-359.

39. Konig B, Konig W, Arnold R, Werchau H, Ihorst G, Forster J: Prospective study of human metapneumovirus infection in children less than 3 years of age. J Clin Microbiol 2004, 42:4632-4635.

40. Maggi F, Pifferi M, Vatteroni M, Fornai C, Tempestini E, Anzilotti S, Lanini L, Andreoli $E$, Ragazzo V, Pistello M, et al: Human metapneumovirus associated with respiratory tract infections in a 3-year study of nasal swabs from infants in Italy. J Clin Microbiol 2003, 41:2987-2991.

41. Wolf DG, Greenberg D, Kalkstein D, Shemer-Avni Y, Givon-Lavi N, Saleh N, Goldberg MD, Dagan R: Comparison of human metapneumovirus, respiratory syncytial virus and influenza $A$ virus lower respiratory tract infections in hospitalized young children. Pediatr Infect Dis J 2006, 25:320-324.
42. Lazar I, Weibel C, Dziura J, Ferguson D, Landry ML, Kahn JS: Human metapneumovirus and severity of respiratory syncytial virus disease. Emerg Infect Dis 2004, 10:1318-1320.

43. Poutanen SM, Low DE, Henry B, Finkelstein S, Rose D, Green K, Tellier R, Draker R, Adachi D, Ayers M, et al: Identification of severe acute respiratory syndrome in Canada. N Engl J Med 2003, 348:1995-2005.

44. Chan PK, Tam JS, Lam CW, Chan E, Wu A, Li CK, Buckley TA, Ng KC, Joynt GM, Cheng FW, et al: Human metapneumovirus detection in patients with severe acute respiratory syndrome. Emerg Infect Dis 2003, 9:1058-1063.

45. Fouchier RA, Kuiken $T$, Schutten M, van Amerongen G, van Doornum GJ, van den Hoogen BG, Peiris M, Lim W, Stohr K, Osterhaus AD: Aetiology: Koch's postulates fulfilled for SARS virus. Nature 2003, 423:240.

46. Choi EH, Lee HJ, Kim SJ, Eun BW, Kim NH, Lee JA, Lee JH, Song EK, Kim SH, Park JY, Sung JY: The association of newly identified respiratory viruses with lower respiratory tract infections in Korean children, 2000-2005. Clin Infect Dis 2006, 43:585-592.

47. Franz A, Adams O, Willems R, Bonzel L, Neuhausen N, Schweizer-Krantz S, Ruggeberg JU, Willers R, Henrich B, Schroten H, Tenenbaum T: Correlation of viral load of respiratory pathogens and co-infections with disease severity in children hospitalized for lower respiratory tract infection. J Clin Virol 2010, 48:239-245.

48. Pyrc K, Sims AC, Dijkman R, Jebbink M, Long C, Deming D, Donaldson E, Vabret A, Baric R, van der Hoek L, Pickles R: Culturing the unculturable: human coronavirus HKU1 infects, replicates, and produces progeny virions in human ciliated airway epithelial cell cultures. J Virol 2010, 84:11255-11263.

49. Bastien N, Anderson K, Hart L, Van Caeseele P, Brandt K, Milley D, Hatchette T, Weiss EC, Li Y: Human coronavirus NL63 infection in Canada. J Infect Dis 2005, 191:503-506.

50. Pyrc K, Berkhout B, van der Hoek L: The novel human coronaviruses NL63 and HKU1. J Virol 2007, 81:3051-3057.

51. Gaunt ER, Hardie A, Claas EC, Simmonds P, Templeton KE: Epidemiology and clinical presentations of the four human coronaviruses 229E, HKU1, NL63, and OC43 detected over 3 years using a novel multiplex real-time PCR method. J Clin Microbiol 2010, 48:2940-2947.

52. Vabret A, Mourez T, Dina J, van der Hoek L, Gouarin S, Petitjean J, Brouard J, Freymuth F: Human coronavirus NL63, France. Emerg Infect Dis 2005, 11:1225-1229.

53. Koetz A, Nilsson $P$, Linden $M$, van der Hoek $L$, Ripa T: Detection of human coronavirus NL63, human metapneumovirus and respiratory syncytial virus in children with respiratory tract infections in south-west Sweden. Clin Microbiol Infect 2006, 12:1089-1096.

54. Jin Y, Zhang RF, Xie ZP, Yan KL, Gao HC, Song JR, Yuan XH, Cheng WX, Hou YD, Duan ZJ: Newly identified respiratory viruses associated with acute lower respiratory tract infections in children in Lanzou, China, from 2006 to 2009. Clin Microbiol Infect 2011, 18:74-80.

55. Chiu SS, Chan KH, Chu KW, Kwan SW, Guan Y, Poon LL, Peiris JS: Human coronavirus NL63 infection and other coronavirus infections in children hospitalized with acute respiratory disease in Hong Kong, China. Clin Infect Dis 2005, 40:1721-1729.

56. Minosse C, Selleri M, Zaniratti MS, Cappiello G, Spano A, Schifano E, Lauria FN, Gualano G, Puro V, Campanini G, et al: Phylogenetic analysis of human coronavirus NL63 circulating in Italy. J Clin Virol 2008, 43:114-119.

57. Dare RK, Fry AM, Chittaganpitch M, Sawanpanyalert P, Olsen SJ, Erdman DD: Human coronavirus infections in rural Thailand: a comprehensive study using real-time reverse-transcription polymerase chain reaction assays. J Infect Dis 2007, 196:1321-1328.

58. Wu PS, Chang LY, Berkhout B, van der Hoek L, Lu CY, Kao CL, Lee PI, Shao PL, Lee CY, Huang FY, Huang LM: Clinical manifestations of human coronavirus NL63 infection in children in Taiwan. Eur J Pediatr 2008, 167:75-80.

59. van der Hoek L, Sure K, Ihorst G, Stang A, Pyrc K, Jebbink MF, Petersen G, Forster J, Berkhout B, Uberla K: Croup is associated with the novel coronavirus NL63. PLoS Med 2005, 2:e240.

60. Kupfer B, Simon A, Jonassen CM, Viazov S, Ditt V, Tillmann RL, Muller A, Matz B, Schildgen $\mathrm{O}$ : Two cases of severe obstructive pneumonia associated with an HKU1-like coronavirus. Eur J Med Res 2007, 12:134-138.

61. Xiao NG, Xie ZP, Zhou QH, Zhang RF, Zhong LL, Gao HC, Ding XF, Li J, Song JR, Hou YD, et al: [Detection and clinical study on coronavirus HKU1 with acute lower respiratory tract infections of hospitalized children in Changsha]. 
Zhonghua Shi Yan He Lin Chuang Bing Du Xue Za Zhi 2011,

25:2-4.

62. Lau SK, Woo PC, Yip CC, Tse H, Tsoi HW, Cheng VC, Lee P, Tang BS, Cheung $\mathrm{CH}$, Lee RA, et al: Coronavirus HKU1 and other coronavirus infections in Hong Kong. J Clin Microbiol 2006, 44:2063-2071.

63. Kuypers J, Martin ET, Heugel J, Wright N, Morrow R, Englund JA: Clinical disease in children associated with newly described coronavirus subtypes. Pediatrics 2007, 119:e70-e76.

64. Fry AM, Lu X, Chittaganpitch M, Peret T, Fischer J, Dowell SF, Anderson L, Erdman D, Olsen SJ: Human bocavirus: a novel parvovirus epidemiologically associated with pneumonia requiring hospitalization in Thailand. J Infect Dis 2007, 195:1038-1045.

65. Soderlund-Venermo M, Lahtinen A, Jartti T, Hedman L, Kemppainen K, Lehtinen P, Allander T, Ruuskanen O, Hedman K: Clinical assessment and improved diagnosis of bocavirus-induced wheezing in children, Finland. Emerg Infect Dis 2009, 15:1423-1430.

66. Kesebir D, Vazquez M, Weibel C, Shapiro ED, Ferguson D, Landry ML, Kahn $J S$ : Human bocavirus infection in young children in the United States: molecular epidemiological profile and clinical characteristics of a newly emerging respiratory virus. J Infect Dis 2006, 194:1276-1282.

67. Maggi F, Andreoli E, Pifferi M, Meschi S, Rocchi J, Bendinelli M: Human bocavirus in Italian patients with respiratory diseases. J Clin Virol 2007, 38:321-325.

68. Allander T, Jartti T, Gupta S, Niesters HG, Lehtinen P, Osterback R, Vuorinen T, Waris M, Bjerkner A, Tiveljung-Lindell A, et al: Human bocavirus and acute wheezing in children. Clin Infect Dis 2007, 44:904-910.

69. Ghietto LM, Camara A, Zhou Y, Pedranti M, Ferreyra S, Frey T, Camara J, Adamo MP: High prevalence of human bocavirus 1 in infants with lower acute respiratory tract disease in Argentina, 2007-2009. Braz J Infect Dis 2012, 16:38-44.

70. Christensen A, Nordbo SA, Krokstad S, Rognlien AG, Dollner H: Human bocavirus commonly involved in multiple viral airway infections. J Clin Virol 2008, 41:34-37.

71. Esposito S, Daleno C, Prunotto G, Scala A, Tagliabue C, Borzani I, Fossali E, Pelucchi C, Principi N: Impact of viral infections in children with community-acquired pneumonia: results of a study of 17 respiratory viruses. Influenza Other Respi Viruses 2012, 11:1750-2659.

72. Kapoor A, Simmonds P, Slikas E, Li L, Bodhidatta L, Sethabutr O, Triki H, Bahri O, Oderinde BS, Baba MM, et al: Human bocaviruses are highly diverse, dispersed, recombination prone, and prevalent in enteric infections. J Infect Dis 2010, 201:1633-1643.

73. Arthur JL, Higgins GD, Davidson GP, Givney RC, Ratcliff RM: A novel bocavirus associated with acute gastroenteritis in Australian children. PLOS Pathog 2009, 5:e1000391.

74. Kantola K, Hedman L, Allander T, Jartti T, Lehtinen P, Ruuskanen O, Hedman K, Soderlund-Venermo M: Serodiagnosis of human bocavirus infection. Clin Infect Dis 2008, 46:540-546.

75. Hedman L, Soderlund-Venermo M, Jartti T, Ruuskanen O, Hedman K: Dating of human bocavirus infection with protein-denaturing lgG-avidity assays-Secondary immune activations are ubiquitous in immunocompetent adults. J Clin Virol 2010, 48:44-48.

76. Don M, Soderlund-Venermo M, Valent F, Lahtinen A, Hedman L, Canciani M, Hedman K, Korppi M: Serologically verified human bocavirus pneumonia in children. Pediatr Pulmonol 2010, 45:120-126.

77. Martin ET, Fairchok MP, Kuypers J, Magaret A, Zerr DM, Wald A, Englund JA: Frequent and prolonged shedding of bocavirus in young children attending daycare. J Infect Dis 2010, 201:1625-1632.

78. Blessing K, Neske F, Herre U, Kreth HW, Weissbrich B: Prolonged detection of human bocavirus DNA in nasopharyngeal aspirates of children with respiratory tract disease. Pediatr Infect Dis J 2009, 28:1018-1019.

79. von Linstow ML, Hogh M, Hogh B: Clinical and epidemiologic characteristics of human bocavirus in Danish infants: results from a prospective birth cohort study. Pediatr Infect Dis J 2008, 27:897-902.

80. Longtin J, Bastien M, Gilca R, Leblanc E, de Serres G, Bergeron MG, Boivin G: Human bocavirus infections in hospitalized children and adults. Emerg Infect Dis 2008, 14:217-221.

81. Manning A, Russell V, Eastick K, Leadbetter GH, Hallam N, Templeton K, Simmonds P: Epidemiological profile and clinical associations of human bocavirus and other human parvoviruses. J Infect Dis 2006, 194:1283-1290.

82. Calvo C, Garcia-Garcia ML, Pozo F, Carvajal O, Perez-Brena P, Casas I: Clinical characteristics of human bocavirus infections compared with other respiratory viruses in Spanish children. Pediatr Infect Dis J 2008, 27:677-680

83. Liu WK, Chen DH, Liu Q, Liang HX, Yang ZF, Qin S, Zhou R: Detection of human bocavirus from children and adults with acute respiratory tract illness in Guangzhou, southern China. BMC Infect Dis 2011, 11:345

84. Schildgen O, Muller A, Allander T, Mackay IM, Volz S, Kupfer B, Simon A: Human bocavirus: passenger or pathogen in acute respiratory tract infections? Clin Microbiol Rev 2008, 21:291-304.

85. Wang K, Wang W, Yan H, Ren P, Zhang J, Shen J, Deubel V: Correlation between bocavirus infection and humoral response, and co-infection with other respiratory viruses in children with acute respiratory infection. J Clin Virol 2010, 47:148-155.

86. Gerna G, Piralla A, Campanini G, Marchi A, Stronati M, Rovida F: The human bocavirus role in acute respiratory tract infections of pediatric patients as defined by viral load quantification. New Microbiol 2007, 30:383-392.

87. Dina J, Nguyen E, Gouarin S, Petitjean J, Parienti JJ, Nimal D, Brouard J, Freymuth F, Vabret A: Development of duplex real-time PCR for detection of two DNA respiratory viruses. J Virol Methods 2009, 162:119-125.

88. Jartti T, Hedman K, Jartti L, Ruuskanen O, Allander T, Soderlund-Venermo M: Human bocavirus-the first 5 years. Rev Med Virol 2010, 22:46-64.

89. Korner RW, Soderlund-Venermo M, van Koningsbruggen-Rietschel S, Kaiser R, Malecki M, Schildgen O: Severe human bocavirus infection, Germany. Emerg Infect Dis 2011, 17:2303-2305.

90. Kean JM, Rao S, Wang M, Garcea RL: Seroepidemiology of human polyomaviruses. PLoS Pathog 2009, 5:e1000363.

91. Neske F, Prifert C, Scheiner B, Ewald M, Schubert J, Opitz A, Weissbrich B: High prevalence of antibodies against polyomavirus WU, polyomavirus $\mathrm{KI}$, and human bocavirus in German blood donors. BMC Infect Dis 2010, $10: 215$.

92. Debiaggi M, Canducci F, Brerra R, Sampaolo M, Marinozzi MC, Parea M, Arghittu M, Alessandrino EP, Nava S, Nucleo E, et al: Molecular epidemiology of $\mathrm{KI}$ and $\mathrm{WU}$ polyomaviruses in infants with acute respiratory disease and in adult hematopoietic stem cell transplant recipients. J Med Virol 2010, 82:153-156.

93. Abedi Kiasari B, Vallely PJ, Corless CE, Al-Hammadi M, Klapper PE: Agerelated pattern of $\mathrm{KI}$ and WU polyomavirus infection. J Clin Virol 2008, 43:123-125

94. Han TH, Chung JY, Koo JW, Kim SW, Hwang ES: WU polyomavirus in children with acute lower respiratory tract infections, South Korea. Emerg Infect Dis 2007, 13:1766-1768.

95. Le BM, Demertzis LM, Wu G, Tibbets RJ, Buller R, Arens MQ, Gaynor AM, Storch GA, Wang D: Clinical and epidemiologic characterization of WU polyomavirus infection, St. Louis, Missouri. Emerg Infect Dis 2007, 13:1936-1938

96. Abed Y, Wang D, Boivin G: WU polyomavirus in children, Canada. Emerg Infect Dis 2007, 13:1939-1941.

97. Bialasiewicz S, Whiley DM, Lambert SB, Jacob K, Bletchly C, Wang D Nissen MD, Sloots TP: Presence of the newly discovered human polyomaviruses $\mathrm{KI}$ and $\mathrm{WU}$ in Australian patients with acute respiratory tract infection. J Clin Virol 2008, 41:63-68.

98. Norja P, Ubillos I, Templeton K, Simmonds P: No evidence for an association between infections with $\mathrm{WU}$ and $\mathrm{KI}$ polyomaviruses and respiratory disease. J Clin Virol 2007, 40:307-311.

99. Zhuang WL, Lu XD, Lin GY, Wu Y, Lin CX, Chen PZ, Xie SX, Zhang N, Ma L: WU polyomavirus infection among children in South China. J Med Virol 2009, 83:1440-1445.

100. Ren L, Gonzalez R, Xie Z, Zhang J, Liu C, Li J, Li Y, Wang Z, Kong X, Yao Y, et al: WU and $\mathrm{KI}$ polyomavirus present in the respiratory tract of children, but not in immunocompetent adults. J Clin Virol 2008, 43:330-333.

101. Mourez T, Bergeron A, Ribaud P, Scieux C, de Latour RP, Tazi A, Socie G, Simon F, LeGoff J: Polyomaviruses $\mathrm{KI}$ and WU in immunocompromised patients with respiratory disease. Emerg Infect Dis 2009, 15:107-109.

102. Sharp CP, Norja P, Anthony I, Bell JE, Simmonds P: Reactivation and mutation of newly discovered $\mathrm{WU}, \mathrm{KI}$, and Merkel cell carcinoma polyomaviruses in immunosuppressed individuals. J Infect Dis 2009, 199:398-404.

103. Babakir-Mina M, Ciccozzi M, Farchi F, Bergallo M, Cavallo R, Adorno G, Perno CF, Ciotti M: KI and WU polyomaviruses and CD4+ cell counts in HIV-1infected patients, Italy. Emerg Infect Dis 2010, 16:1482-1485. 
104. Huijskens EG, van Erkel AJ, Peeters MF, Rossen JW: Human polyomavirus KI and WU in adults with community acquired pneumonia in The Netherlands, 2008-2009. J Clin Virol 2010, 49:306-307.

105. Rao S, Garcea RL, Robinson CC, Simoes EA: WU and KI polyomavirus infections in pediatric hematology/oncology patients with acute respiratory tract illness. J Clin Virol 2011, 52:28-32.

106. Bochkov YA, Gern JE: Clinical and molecular features of human rhinovirus C. Microbes Infect 2012, 14:485-494.

107. Lamson D, Renwick N, Kapoor V, Liu Z, Palacios G, Ju J, Dean A, St George K, Briese T, Lipkin WI: MassTag polymerase-chain-reaction detection of respiratory pathogens, including a new rhinovirus genotype, that caused influenza-like illness in New York State during 2004-2005. J Infect Dis 2006, 194:1398-1402.

108. McErlean P, Shackelton LA, Lambert SB, Nissen MD, Sloots TP, Mackay IM: Characterisation of a newly identified human rhinovirus, HRV-QPM, discovered in infants with bronchiolitis. J Clin Virol 2007, 39:67-75.

109. Tapparel C, L'Huillier AG, Rougemont AL, Beghetti M, Barazzone-Argiroffo C, Kaiser L: Pneumonia and pericarditis in a child with HRV-C infection: a case report. J Clin Virol 2009, 45:157-160.

110. Arden KE, Mackay IM: Newly identified human rhinoviruses: molecular methods heat up the cold viruses. Rev Med Virol 2010, 20:156-176.

111. Lau SK, Yip CC, Tsoi HW, Lee RA, So LY, Lau YL, Chan KH, Woo PC, Yuen KY: Clinical features and complete genome characterization of a distinct human rhinovirus (HRV) genetic cluster, probably representing a previously undetected HRV species, HRV-C, associated with acute respiratory illness in children. J Clin Microbiol 2007, 45:3655-3664.

112. Khetsuriani N, Lu X, Teague WG, Kazerouni N, Anderson LJ, Erdman DD: Novel human rhinoviruses and exacerbation of asthma in children. Emerg Infect Dis 2008, 14:1793-1796.

113. Miller EK, Edwards KM, Weinberg GA, Iwane MK, Griffin MR, Hall CB, Zhu Y, Szilagyi PG, Morin LL, Heil LH, et al: A novel group of rhinoviruses is associated with asthma hospitalizations. J Allergy Clin Immunol 2009, 123:98-104.

114. Wisdom A, Kutkowska AE, McWilliam Leitch EC, Gaunt E, Templeton K, Harvala $H$, Simmonds P: Genetics, recombination and clinical features of human rhinovirus species $\mathrm{C}$ (HRV-C) infections; interactions of HRV-C with other respiratory viruses. PLoS One 2009, 4:8518.

115. Xiang Z, Gonzalez R, Xie Z, Xiao Y, Liu J, Chen L, Liu C, Zhang J, Ren L, Vernet $G$, et al: Human rhinovirus $C$ infections mirror those of human rhinovirus $A$ in children with community-acquired pneumonia. J Clin Virol 2010, 49:94-99.

116. Louie JK, Roy-Burman A, Guardia-Labar L, Boston EJ, Kiang D, Padilla T, Yagi S, Messenger S, Petru AM, Glaser CA, Schnurr DP: Rhinovirus associated with severe lower respiratory tract infections in children. Pediatr Infect Dis J 2009, 28:337-339.

117. Jin Y, Yuan XH, Xie ZP, Gao HC, Song JR, Zhang RF, Xu ZQ, Zheng LS, Hou $Y D$, Duan ZJ: Prevalence and clinical characterization of a newly identified human rhinovirus $\mathrm{C}$ species in children with acute respiratory tract infections. J Clin Microbiol 2009, 47:2895-2900.

118. Xiang Z, Gonzalez R, Xie Z, Xiao Y, Chen L, Li Y, Liu C, Hu Y, Yao Y, Qian S, et al: Human rhinovirus group $C$ infection in children with lower respiratory tract infection. Emerg Infect Dis 2008, 14:1665-1667.

119. Linsuwanon P, Payungporn S, Samransamruajkit R, Posuwan N, Makkoch J, Theanboonlers A, Poovorawan Y: High prevalence of human rhinovirus $C$ infection in Thai children with acute lower respiratory tract disease. J Infect 2009, 59:115-121.

120. Greer RM, McErlean P, Arden KE, Faux CE, Nitsche A, Lambert SB, Nissen MD, Sloots TP, Mackay IM: Do rhinoviruses reduce the probability of viral co-detection during acute respiratory tract infections? J Clin Virol 2009, 45:10-15.

121. Tapparel C, Junier T, Gerlach D, Van-Belle S, Turin L, Cordey S, Muhlemann K, Regamey N, Aubert JD, Soccal PM, et al: New respiratory enterovirus and recombinant rhinoviruses among circulating picornaviruses. Emerg Infect Dis 2009, 15:719-726.

122. Piralla A, Rovida F, Baldanti F, Gerna G: Enterovirus genotype EV-104 in humans, Italy, 2008-2009. Emerg Infect Dis 2010, 16:1018-1021.

123. Grard G, Drexler JF, Lekana-Douki S, Caron M, Lukashev A, Nkoghe D, Gonzalez JP, Drosten C, Leroy E: Type 1 wild poliovirus and putative enterovirus 109 in an outbreak of acute flaccid paralysis in Congo, October-November. Euro Surveill 2010, 15.
124. Debiaggi M, Ceresola ER, Sampaolo M, Alessandrino EP, Brerra R, Piazza A, Saita D, Clementi M, Canducci F: Epidemiological, molecular and clinical features of Enterovirus 109 infection in children and in adult stem cell transplant recipients. Virol J 2012, 9:183.

125. Pankovics P, Boros A, Szabo H, Szekely G, Gyurkovits K, Reuter G: Human enterovirus 109 (EV109) in acute paediatric respiratory disease in Hungary. Acta Microbiol Immunol Hung 2012, 59:285-290.

126. Al-Sunaidi M, Williams CH, Hughes PJ, Schnurr DP, Stanway G: Analysis of a new human parechovirus allows the definition of parechovirus types and the identification of RNA structural domains. J Virol 2007, 81:1013-1021.

127. Benschop KS, Schinkel J, Minnaar RP, Pajkrt D, Spanjerberg L, Kraakman HC, Berkhout B, Zaaijer HL, Beld MG, Wolthers KC: Human parechovirus infections in Dutch children and the association between serotype and disease severity. Clin Infect Dis 2006, 42:204-210.

128. Ito M, Yamashita T, Tsuzuki H, Takeda N, Sakae K: Isolation and identification of a novel human parechovirus. J Gen Virol 2004, 85:391-398.

129. Watanabe K, Oie M, Higuchi M, Nishikawa M, Fujii M: Isolation and characterization of novel human parechovirus from clinical samples. Emerg Infect Dis 2007, 13:889-895.

130. Boivin G, Abed Y, Boucher FD: Human parechovirus 3 and neonatal infections. Emerg Infect Dis 2005, 11:103-105.

131. Kim Pham NT, Trinh QD, Takanashi S, Abeysekera C, Abeygunawardene A, Shimizu H, Khamrin P, Okitsu S, Mizuguchi M, Ushijima H: Novel human parechovirus, Sri Lanka. Emerg Infect Dis 2010, 16:130-132.

132. Drexler JF, Grywna K, Stocker A, Almeida PS, Medrado-Ribeiro TC, EschbachBludau M, Petersen N, da Costa-Ribeiro-Jr H, Drosten C: Novel human parechovirus from Brazil. Emerg Infect Dis 2009, 15:310-313.

133. Calvert J, Chieochansin T, Benschop KS, McWilliam Leitch EC, Drexler JF, Grywna K, da Costa Ribeiro H Jr, Drosten C, Harvala H, Poovorawan Y, et al: Recombination dynamics of human parechoviruses: investigation of type-specific differences in frequency and epidemiological correlates. J Gen Virol 2010, 91:1229-1238.

134. Li L, Victoria J, Kapoor A, Naeem A, Shaukat S, Sharif S, Alam MM, Angez M, Zaidi SZ, Delwart E: Genomic characterization of novel human parechovirus type. Emerg Infect Dis 2009, 15:288-291.

135. Harvala H, Robertson I, McWilliam Leitch EC, Benschop K, Wolthers KC, Templeton K, Simmonds P: Epidemiology and clinical associations of human parechovirus respiratory infections. J Clin Microbiol 2008, 46:3446-3453.

136. Piralla A, Furione M, Rovida F, Marchi A, Stronati M, Gerna G, Baldanti F: Human parechovirus infections in patients admitted to hospital in Northern Italy, 2008-2010. J Med Virol 2012, 84:686-690.

137. Echevarria-Zuno S, Mejia-Arangure JM, Mar-Obeso AJ, Grajales-Muniz C, Robles-Perez E, Gonzalez-Leon M, Ortega-Alvarez MC, Gonzalez-Bonilla C, Rascon-Pacheco RA, Borja-Aburto VH: Infection and death from influenza A H1N1 virus in Mexico: a retrospective analysis. Lancet 2009, 374:2072-2079.

138. Lopez-Cervantes M, Venado A, Moreno A, Pacheco-Dominguez RL, OrtegaPierres $\mathrm{G}$ : On the spread of the novel influenza $A(\mathrm{H} 1 \mathrm{~N} 1)$ virus in Mexico. J Infect Dev Ctries 2009, 3:327-330.

139. Peiris JS, Poon LL, Guan Y: Emergence of a novel swine-origin influenza $A$ virus (S-OIV) H1N1 virus in humans. J Clin Virol 2009, 45:169-173.

140. Dawood FS, Jain S, Finelli L, Shaw MW, Lindstrom S, Garten RJ, Gubareva LV, Xu X, Bridges CB, Uyeki TM: Emergence of a novel swine-origin influenza A (H1N1) virus in humans. N Engl J Med 2009, 360:2605-2615.

141. Perez P, la Rosa D, Zamboni D, Ponce De Leon S, Hernandez M, Quinones Falconi F, Bautista E, Ramirez Venegas A, Rojas Serrano J, Ormsby CE, Corrales $A$, et al: Pneumonia and respiratory failure from swine-origin influenza A (H1N1) in Mexico. N Engl J Med 2009, 361:680-689.

142. Jain S, Kamimoto L, Bramley AM, Schmitz AM, Benoit SR, Louie J, Sugerman DE, Druckenmiller JK, Ritger KA, Chugh R, et al: Hospitalized patients with 2009 H1N1 influenza in the United States, April-June 2009. N Engl J Med 2009, 361:1935-1944.

143. Burioni R, Canducci F, Mancini N, Clementi N, Sassi M, De Marco D, Diotti RA, Saita D, Sampaolo M, Sautto G, et al: Monoclonal antibodies isolated from human $B$ cells neutralize a broad range of $\mathrm{H} 1$ subtype influenza $A$ viruses including swine-origin Influenza virus (S-OIV). Virology 2010, 399:144-152.

144. Burioni R, Canducci F, Mancini N, Clementi N, Sassi M, De Marco D, Saita D, Diotti RA, Sautto G, Sampaolo M, Clementi M: Molecular cloning of the first human monoclonal antibodies neutralizing with high potency swine-origin influenza A pandemic virus (S-OIV). New Microbiol 2009, 32:19-324. 
145. Burioni R, Canducci F, Clementi M: Pregnancy and H1N1 infection. Lancet 2009, 374:1417-1418.

146. Ison MG, Lee N: Influenza 2010-2011: lessons from the 2009 pandemic. Cleve Clin J Med 2010, 77:812-820.

147. Libster R, Bugna J, Coviello S, Hijano DR, Dunaiewsky M, Reynoso N, Cavalieri ML, Guglielmo MC, Areso MS, Gilligan T, et al: Pediatric hospitalizations associated with 2009 pandemic influenza A (H1N1) in Argentina. N Engl J Med 2010, 362:45-55.

148. Miller E, Hoschler K, Hardelid P, Stanford E, Andrews N, Zambon M: Incidence of 2009 pandemic influenza A H1N1 infection in England: a cross-sectional serological study. Lancet 2010, 375:1100-1108.

149. Sachedina N, Donaldson LJ: Paediatric mortality related to pandemic influenza A H1N1 infection in England: an observational populationbased study. Lancet 2010, 376:1846-1852.

150. Skarbinski J, Jain S, Bramley A, Lee EJ, Huang J, Kirschke D, Stone A, Wedlake T, Richards SM, Page S, et al: Hospitalized patients with 2009 pandemic influenza $A(\mathrm{H} 1 \mathrm{~N} 1)$ virus infection in the United States-SeptemberOctober 2009. Clin Infect Dis 2012, 52(Suppl 1):S50-S59.

151. Lister P, Reynolds F, Parslow R, Chan A, Cooper M, Plunkett A, Riphagen S, Peters M: Swine-origin influenza virus $\mathrm{H} 1 \mathrm{~N} 1$, seasonal influenza virus, and critical illness in children. Lancet 2009, 374:605-607.

152. Louie JK, Gavali S, Acosta M, Samuel MC, Winter K, Jean C, Glaser CA, Matyas BT, Schechter R: Children hospitalized with 2009 novel influenza A(H1N1) in California. Arch Pediatr Adolesc Med 2010, 164:1023-1031.

153. Miroballi Y, Baird JS, Zackai S, Cannon JM, Messina M, Ravindranath T, Green R, Della-Latta P, Jenkins S, Greenwald BM, et al: Novel influenza A(H1N1) in a pediatric health care facility in New York City during the first wave of the 2009 pandemic. Arch Pediatr Adolesc Med 2010, 164:24-30.

154. Schnepf N, Resche-Rigon M, Chaillon A, Scemla A, Gras G, Semoun O, Taboulet P, Molina JM, Simon F, Goudeau A, LeGoff J: High burden of noninfluenza viruses in influenza-like illness in the early weeks of H1N1v epidemic in France. PLoS One 2011, 6:e23514.

155. Renois F, Talmud D, Huguenin A, Moutte L, Strady C, Cousson J, Leveque $\mathrm{N}$, Andreoletti L: Rapid detection of respiratory tract viral infections and coinfections in patients with influenza-like illnesses by use of reverse transcription-PCR DNA microarray systems. J Clin Microbiol 2010, 48:3836-3842.

156. Casalegno JS, Ottmann M, Duchamp MB, Escuret V, Billaud G, Frobert E, Morfin F, Lina B: Rhinoviruses delayed the circulation of the pandemic influenza A (H1N1) 2009 virus in France. Clin Microbiol Infect 2010, 16:326-329.

157. Hino S: TTV, a new human virus with single stranded circular DNA genome. Rev Med Virol 2002, 12:151-158.

158. Bendinelli M, Pistello M, Maggi F, Fornai C, Freer G, Vatteroni ML: Molecular properties, biology, and clinical implications of $\Pi T$ virus, a recently identified widespread infectious agent of humans. Clin Microbiol Rev 2001, 14:98-113.

159. Maggi F, Pifferi M, Fornai C, Andreoli E, Tempestini E, Vatteroni M, Presciuttini S, Marchi S, Pietrobelli A, Boner A, et al: $T$ virus in the nasal secretions of children with acute respiratory diseases: relations to viremia and disease severity. J Virol 2003, 77:2418-2425.

160. Pifferi M, Maggi F, Andreoli E, Lanini L, Marco ED, Fornai C, Vatteroni ML, Pistello M, Ragazzo V, Macchia P, et al: Associations between nasal torquetenovirus load and spirometric indices in children with asthma. J Infect Dis 2005, 192:1141-1148.

161. Pifferi M, Maggi F, Di Cristofano C, Cangiotti AM, Nelli LC, Bevilacqua G, Macchia P, Bendinelli M, Boner AL: Torquetenovirus infection and ciliary dysmotility in children with recurrent pneumonia. Pediatr Infect Dis $J$ 2008, 27:413-418.

doi:10.1186/1743-422X-9-247

Cite this article as: Debiaggi et al:: The role of infections and coinfections with newly identified and emerging respiratory viruses in children. Virology Journal 2012 9:247.

\section{Submit your next manuscript to BioMed Central and take full advantage of:}

- Convenient online submission

- Thorough peer review

- No space constraints or color figure charges

- Immediate publication on acceptance

- Inclusion in PubMed, CAS, Scopus and Google Scholar

- Research which is freely available for redistribution

Submit your manuscript at www.biomedcentral.com/submit
C Biomed Central 